\title{
Kebijakan Editorial Surat Kabar Harian Medan Bisnis dalam Pemberritaan Masalah Ekonomi dan Bisnis
}

\author{
Nurhalim Tanjung \\ Sekolah Tinggi Ilmu Komunikasi "Pembangunan" \\ Jalan SM Raja Medan, Indonesia \\ Koresponden: nurhalimtanjung@gmail.com
}

\begin{abstract}
ABSTRAK
Penelitian ini mencoba mengungkapkan kebijakan editorial suratkabar Harian MedanBisnis dalam pemberitaan masalah ekonomi dan bisnis dengan menggunakan teori agenda setting media dan hierarki pengaruh. Metode dalam penelitian ini menggunakan pendekatan kualitatif yang bersifat deskriptif. Penelitian dilakukan dalam periode waktu Maret-Desember 2014. Hasil penelitian ini menunjukkan Harian MedanBisnis merupakan suratkabar ekonomi lokal yang memprioritaskan pemberitaan sektor ekonomi dan bisnis berskala mikro. Namun berita ekonomi makro dan nasional maupun internasional juga menjadi perhatian suratkabar ini jika berdampak kepada masyarakat lokal di Sumatera Utara. Selain itu lima level sebagai faktor "hierarki pengaruh" ikut memengaruhi kebijakan editorial Harian MedanBisnis dalam pemberitaan masalah ekonomi dan bisnis.
\end{abstract}

Kata Kunci : Kebijakan Editorial, Surat Kabar Ekonomi dan Bisnis, Agenda Setting, Hierarki Pengaruh

\begin{abstract}
This study attempts to reveal the editorial policy of MedanBisnis Daily newspaper in reporting economic and business issues using agenda theory of media settings and influence hierarchies. The method in this study uses a descriptive qualitative approach. The study was conducted in the period March-December 2014.The results of this study indicate the Medan Daily Business is a local economic newspaper that prioritizes reporting on the economic sector and micro-scale business. But the macro and national and international economic news is also a concern for this newspaper if it impacts on the local community in North Sumatra. In addition, the five levels as a factor of "hierarchy of influence" influenced the MedanBisnis Daily editorial policy in reporting economic and business issues.
\end{abstract}

Keywords : Editorial Policy, Economic and Business Newspaper, Agenda Setting, Influence Hierarchy

\section{Pendahuluan}

Masyarakat mengandalkan pers, termasuk suratkabar sebagai sumber informasi untuk menentukan langkah dalam kegiatan sehari-hari. Grant M. Hyde menyebutkan suratkabar merupakan sumber informasi bagi masyarakat, dimana mereka memperoleh fakta-fakta sebagai dasar pendapat atau pandangannya (Atmadi., 1975: 238).

Dewasa ini perkembangan kehidupan di abad millenium membuat kebutuhan masyarakat terhadap informasi menjadi semakin beragam. Para politisi membutuhkan informasi politik, penggemar olahraga memerlukan informasi mengenai sepakbola dan event olahraga lainnya, sedangkan para pebisnis sangat membutuhkan informasi mengenai perekonomian. Mereka memerlukan informasi yang sesuai kebutuhannya untuk mendukung kegiatan dan aktivitas masing-masing.

Kondisi itu membuat para pengelola suratkabar berusaha menyajikan berita-berita spesifik untuk memenuhi kebutuhan masyarakat, yang kemudian dilihat sebagai peluang untuk bertahan dan berkembang dalam kompetisi era pers industri saat ini. Severrin - Tankard (2005: 232) mengemukakan komunikasi massa perlu mengaplikasikan segmentasi audiensi (audiensce segmentation). Cara ini akan membuat media massa memproduksi pesan atau berita-berita spesifik untuk kelompok audien dalam segmentasinya tersebut. 
Vol 1 No. 1, 2018, 15-48

DOI: https://doi.org/10.30596/persepsi.v1i1.2504

Shoemaker dan Reese mengatakan organisasi media merupakan entitas sosial, formal, juga entitas ekonomi yang mempekerjakan awak untuk memproduksi konten media tersebut. Mereka mempunyai tujuan mendapatkan profit, karena itu menetapkan audiensi secara khusus guna memikat pemasang iklan (Jorgensen dan Hanitzsch, 2009:61).

Fuller (1996: 70) menegaskan untuk survive suratkabar memang harus merefleksikan audiens yang spesifik, antara lain mampu menjadi cermin bagi masyarakat di daerah tertentu yang menjadi pasarnya. Makanya saat ini bermunculan suratkabar spesialis yang mengkhususkan pemberitaannya terhadap permasalahan tertentu di setiap di daerah. Misalnya, suratkabar politik, suratkabar olahraga, suratkabar kriminal, suratkabar lifestyle, dan suratkabar ekonomi. Para pengelola suratkabar menangkapnya sebagai peluang bisnis, selain bertujuan melayani kebutuhan publik terhadap informasi tersebut.

Satu suratkabar spesialis itu adalah Harian MedanBisnis. Suratkabar yang terbit setiap hari di Medan sejak 31 Juli 2001 ini mengkhususkan pemberitaannya pada permasalahan ekonomi dan bisnis, sekalipun masih memberikan porsi secukupnya pada berita-berita non-ekonomi. Saat ini MedanBisnis sudah memiliki tiras sekira 20.000 eksemplar per hari, dimana 50\% diantaranya mengisi pasar pembaca di Kotamadya Medan dan sekitarnya, sedangkan sisanya beredar di daerah-daerah tingkat dua di Sumatera Utara, di samping juga didistribusikan ke Aceh dan Jakarta. (Profile MedanBisnis, 2013).

Orientasi pemberitaan Harian MedanBisnis terhadap permasalahan ekonomi dan bisnis membuatnya menjadi suratkabar yang berbeda di Medan dan Sumatera Utara, mengingat mayoritas media cetak di daerah ini berlabel suratkabar umum, suratkabar politik, suratkabar kriminal, dan sebagian suratkabar olahraga. Suratkabar-suratkabar itu tentu mempunyai karakter masing-masing, yang dibangun dari editorial policy atau kebijakan editorial yang sudah ditetapkan sebagai spesialisasinya. Jacob Oetama menyebut kebijakan editorial itu sebagai politik pemberitaan. Menurutnya, pengelola suratkabar merumuskan politik pemberitaan berdasarkan kepentingan pembaca dan sikap dasar suratkabar yang bersangkutan (Oetama, 1987: 176).

Harian MedanBisnis juga merumuskan kebijakan editorial berdasarkan kepentingan para pebisnis, pelaku ekonomi, pemerhati masalah ekonomi dan bisnis sebagai pembacanya. Sasaran pemberitaan ini sudah tercermin dari sikap dasar Harian MedanBisnis yang memberi perhatian khusus terhadap permasalahan ekonomi dan bisnis, terutama di Medan Sumatera Utara dan sebagian Aceh.

Warren Breed dalam artikel Social Control in the Newsroom mengemukakan penerbit suratkabar sebagai pemilik atau representasi pemilik memiliki hak untuk menetapkan dan memberlakukan kebijakan editorial suratkabar (Severin-Tankard, 2005: 401). Selain itu setiap media massa, termasuk suratkabar memiliki pemimpin redaksi yang bertanggungjawab penuh untuk masalah pemberitaan. Djuroto (2004: 19) mengatakan pemimpin redaksi memiliki kebijakan dan wewenang untuk masalah penayangan berita, dia mengendalikan kegiatan keredaksian yang meliputi penyajian berita, penentuan liputan, pencarian fokus pemberitaan, penentuan topik, dan pemilihan berita utama. Djuroto (2004: 25) mengemukakan pula pemimpin redaksi dibantu oleh redaktur pelaksana, redaktur, reporter, dan koresponden dalam kegiatan pemberitaan.

Dengan demikian penentuan dan pelaksanaan kebijakan editorial suratkabar juga melibatkan pemimpin redaksi, meski penerbit sebagai pemilik atau representasi pemilik suratkabar memiliki hak memberlakukannya. Begitu pula di Harian MedanBisnis sebagai suratkabar khusus dalam pemberitaan masalah ekonomi dan bisnis.

Kamus Besar Bahasa Indonesia (KBBI, 2005: 287) menyebutkan ekonomi merupakan ilmu mengenai asas-asas produksi, distribusi, dan pemakaian barang-barang serta kekayaan, seperti hal keuangan, perindustrian, dan perdagangan, sedangkan bisnis merupakan usaha komersial dalam dunia perdagangan (KBBI, 2005: 157).

Dalam ilmu ekonomi, menurut Sukirno (2013: 4-5), ada mikroekonomi dan makroekonomi. Mikroekonomi pada umumnya meliputi bagian-bagian kecil dari keseluruhan kegiatan 
perekonomian. Dalam teori mikroekonomi yang dianalisis adalah kegiatan seorang konsumen, suatu perusahaan atau suatu pasar.

Adapun makroekonomi lebih global atau lebih menyeluruh sifatnya. Hasanah dan Danang (2013: 21) mengatakan secara makro, permasalahan perekonomian berkaitan dengan kebijaksanaan yang diambil oleh pemerintah dalam rangka memacu dan mengendalikan laju perekonomian itu sendiri agar dapat berjalan seimbang, selarasa dengan instrumen kekuatan ekonomi yang dimiliki serta aman dan terhindar dari hambatan-hambatan yang dapat mengganggu keseimbangan ekonomi.

Maka berita masalah ekonomi dan bisnis dapat berupa miroekonomi dan makroekonomi. Pemberitaan masalah ini dapat diartikan sebagai informasi mengenai kebijaksanaan pemerintah dalam perekonomian, asas produksi, distribusi, dan pemakaian barang-barang serta kekayaan yang dikelola sebagai usaha komersial dalam dunia usaha dan perdagangan.

Hemp (1991: 7) mengemukakan pemberitaan mengenai ekonomi dan bisnis sangat diperlukan di dunia, terutama di negara berkembang untuk memacu perekonomian. Karena itu banyak media massa mengkhususkan pemberitaannya

terhadap permasalahan ini guna mengembangkan kehidupan setiap orang, mulai dari bankir hingga para konsumen beras di pasar.

Jacob Oetama saat berbicara dalam lokakarya "Peliputan dan Penulisan Berita Ekonomi dan Bisnis untuk Wartawan Media Cetak" di Bogor menyebutkan

pemberitaan mengenai ekonomi dan bisnis yang menjadi kebijakan prioritas pers di Jepang, seperti suratkabar Asahi Shimbun dan media massa lainnya di sana pasca Perang Dunia II membuat negara tersebut tumbuh menjadi kekuatan ekonomi Asia yang diperhitungkan dunia. Padahal kekalahan dalam perang telah menyebabkan negara itu porak poranda, tetapi pemberitaan pers mengenai ekonomi dan bisnis menyadarkan masyarakat Jepang untuk berbenah, meninggalkan kemelaratan. Mereka terpacu untuk membangun ekonomi bangsa. (Waspada, Senin 17 Juni 1996)

Suratkabar ekonomi dan bisnis sebagaimana layaknya media juga perlu mempertimbangkan faktor proximity atau kedekatan dengan pembaca dalam pemberitaannya guna memacu perekonomian. Stieler dan Lippmann mengatakan

kedekatan tersebut bisa berupa fisik maupun emosional (Safrodin, 2010: 4). Kedekatan fisik dapat dilihat dari lokalitas kejadian, yang berarti semakin lokal peristiwa maka ia akan mempunyai nilai berita yang tinggi bagi bagi pembaca di daerah sekitarnya, sedangkan kedekatan emosional dapat dicontohkan melalui success story (kisah sukses) pengusaha kuliner asal Sumatera Utara di Malaysia

misalnya - meski jauh secara fisik tetapi kesamaan daerah asal akan menimbulkan kedekatan bagi pembaca di daerah ini.

Faktor proximity itu semakin penting seiring berlakunya otonomi daerah di Indonesia. Mustoffa (1996: 6-7) mengemukakan prinsip otonomi di Indonesia ditandai dua hal: pergeseran pelaksanaan pembangunan lebih besar kepada pihak swasta dan perpindahan titik berat (pembangunan) ke daerah. Maka otonomi akan membuat daerah menjadi titik sentral pembangunan, demikian pula kegiatan perusahaan, baik swasta maupun Badan Usaha Milik Negara (BUMN) sebagai kegiatan perekonomian mikro dalam kerangka kegiatan perekonomian nasional (makro) turut menjadi titik berat pembangunan di Indonesia. Karena itu kedua perubahan tersebut seharusnya menjadi perhatian suratkabar dalam menentukan kebijakan editorial untuk memacu perekonomian dan bisnis di daerah, yaitu dengan menitikberatkan pemberitaan pada masalah perekonomian di daerah dan berskala mikro, menggantikan prioritas pemberitaan ekonomi yang sebelumnya cenderung bersifat makro dan terpusat kala pemerintahan masih sentralistis.

Deskripsi tersebut menunjukkan kebijakan editorial media massa juga tak terlepas dari situasi dan kondisi masyarakat yang didorong oleh kebijakan strategis pemerintah. De Rooy mengatakan pers di suatu negara akan selalu dipengaruhi oleh pikiran dasar dan orientasi pokok yang sedang berlaku di masyarakatnya (Oetama, 1987: 176). Contohnya, kebangkitan ekonomi 
Jepang pasca Perang Dunia II yang didorong oleh pers yang memprioritaskan pemberitaan ekonomi dan bisnis tak lain dipengaruhi kebijakan strategis pemerintah negara tersebut untuk survive dari tekanan dunia masa itu.

Maka peneliti termotivasi melakukan studi mengenai kebijakan editorial suratkabar ekonomi dan bisnis di Medan, Sumatera Utara, untuk mengetahui sikap dasar suratkabar itu menunaikan apa yang menjadi visi dan misinya dalam menyampaikan pesan berupa pemberitaan ekonomi dan bisnis.

Mengacu uraian latarbelakang masalah dan batasan masalah di atas maka permasalahan dalam penelitian ini adalah mengenai kebijakan editorial suratkabar Harian MedanBisnis dengan melihat konsistensi dan kesinambungannya dalamenyajikan masalah ekonomi dan bisnis. Seterusnya masalah tersebut dapat dirumuskan sebagai berikut:

1. Bagaimanakah kebijakan editorial pemberitaan suratkabar Harian MedanBisnis dalam pemberitaan masalah ekonomi dan bisnis.

2. Bagaimana proses penentuan kebijakan editorial suratkabar Harian MedanBisnis dalam pemberitaan masalah ekonomi dan bisnis.

3. Apakah faktor-faktor yang dipertimbangkan Harian MedanBisnis dalam menentukan kebijakan editorial dalam pemberitaan masalah ekonomi dan bisnis.

Suratkabar Sebagai Media Komunikasi Massa

Suratkabar sebagai media massa cetak merupakan lembaga yang menyebarkan informasi atau berita hasil karya jurnalistik kepada masyarakat. Jadi suratkabar merupakan bentuk media komunikasi massa, dimana pesan yang berbentuk berita disampaikan oleh sumber melembaga yang mampu menembus ruang dan waktu untuk menjangkau khlayak yang bersifat massal dan meluas. Bitner (dalam Rakhmat, 1992: 213) mengatakan komunikasi massa adalah pesan yang dikomunikasikan melalui media massa pada sejumlah besar orang.

Rakhmat (1992: 214) menyebutkan ciri-ciri khusus komunikasi massa sebagai jenis komunikasi yang ditujukan kepada sejumlah khalayak yang tersebar, heterogen, dan anonim, melalui cetak atau elektronik sehingga pesan yang sama dapat diterima secara serentak dan sesaat. Devito (1997: 17) menegaskan komunikasi massa adalah komunikasi dengan radio, televisi, surat kabar, majalah, hasil rekaman radio kaset dan piringahitam.

Penjelasan di atas menunjukkan suratkabar juga disebut sebagai media komunikasi massa atau media massa. Suratkabar boleh dikatakan sebagai media massa tertua karena sudah ada sebelum ditemukan radio, televisi, film, dan media online di komputer. Effendy (1993: 36) menyebutkan suratkabar adalah lembaran tercetak yang memuat laporan yang terjadi di masyarakat dengan ciri-ciri: publisitas (disebarluaskan kepada publik), periodisitas (terbit secara teratur setiap hari, seminggu sekali atau dua mingguan), universalitas (isi surat kabar tersebut bersifat umum yang menyangkut segala aspek kehidupan) dan aktualitas (yang dimuat suratkabar mengenai permasalahan aktual).

Meinanda (1981: 44) mengemukakan suratkabar merupakan alat media cetak yang mempunyai peran sebagai penghubung batiniah dan santapan rohanian sebagai bekal pengetahuan manusia. Selain itu suratkabar berfungsi sebagai alat kontrol sosial yang memberikan penerangan kepada masyarakat, serta mendidik mereka untuk kehidupan di kemudian hari.

Cangara (2004: 127) mengemukakan suratkabar dapat dibedakan atas periode terbit, ukuran, dan sifat penerbitannya. Dari segi periode terbit suratkabar dapat dibedakan atas dua macam, yakni suratkabar harian dan suratkabar mingguan. Suratkabar harian terbit setiap hari dalam bentuk edisi pagi maupun edisi sore, sedangkan suratkabar mingguan terbit paling sedikit satu kali dalam seminggu. Dari segi ukurannya, suratkabar ada yang terbit dalam bentuk plano dan ada pula yang terbit dalam bentuk tabloid. Sedangkan dari segi isinya, suratkabar dapat dibedakan atas dua macam, yakni suratkabar yang bersifat umum dan suratkabar yang bersifat khusus. Suratkabar yang bersifat umum isinya terdiri atas berbagai macam informasi yang ditujukan untuk masyarakat umum, sedangkan suratkabar yang bersifat khusus isinya memiliki ciri khas tertentu dan memiliki pembaca tertentu pula. 
Kebijakan Editorial

Ada dua jenis kebijakan dalam lembaga penerbitan pers. Dominick (dalam Rakhmat, 1992: 243) menyebutkan kedua jenis kebijakan itu sebagai berikut:

1. Operating Policy (kebijakan operasional). Kebijakan ini menyangkut peliputan berita sehari-hari ataupun mengenai situasi yang timbul setiap hari.

2. Editorial Policy (kebijakan redaksional). Kebijakan ini diikuti sikap komunikator untuk memengaruhi khalayak mengenai suatu isu tertentu untuk mencapai tujuan tertentu.

Kebijakan operasional dapat disebutkan sebagai pedoman umum tentang kerja pers sesuai regulasi dari pemerintah dan kode etik pers, sedangkan kebijakan redaksional atau kebijakan editorial menyangkut isi berita yang disajikan oleh redaksi sesuai visi dan misi yang dibawa oleh media tersebut. Karena itu, Broder (1996: 15) mengemukakan, hampir semua media massa mempunyai kebijakan operasional yang sama sebagaimana tertuang dalam undang-undang dan kode etik jurnalistik yang berlaku. Sedangkan kebijakan editorial, setiap media massa punya perbedaan satu dengan lainnya sesuai dengan visi dan misi masing-masing.

Selain itu, Pamela J. Shoemaker dan Stephen D. Reese (Yusuf, 2011: 311) menyebut ada lima level sebagai faktor yang ikut memengaruhi kebijakan editorial media dalam memproduksi berita.

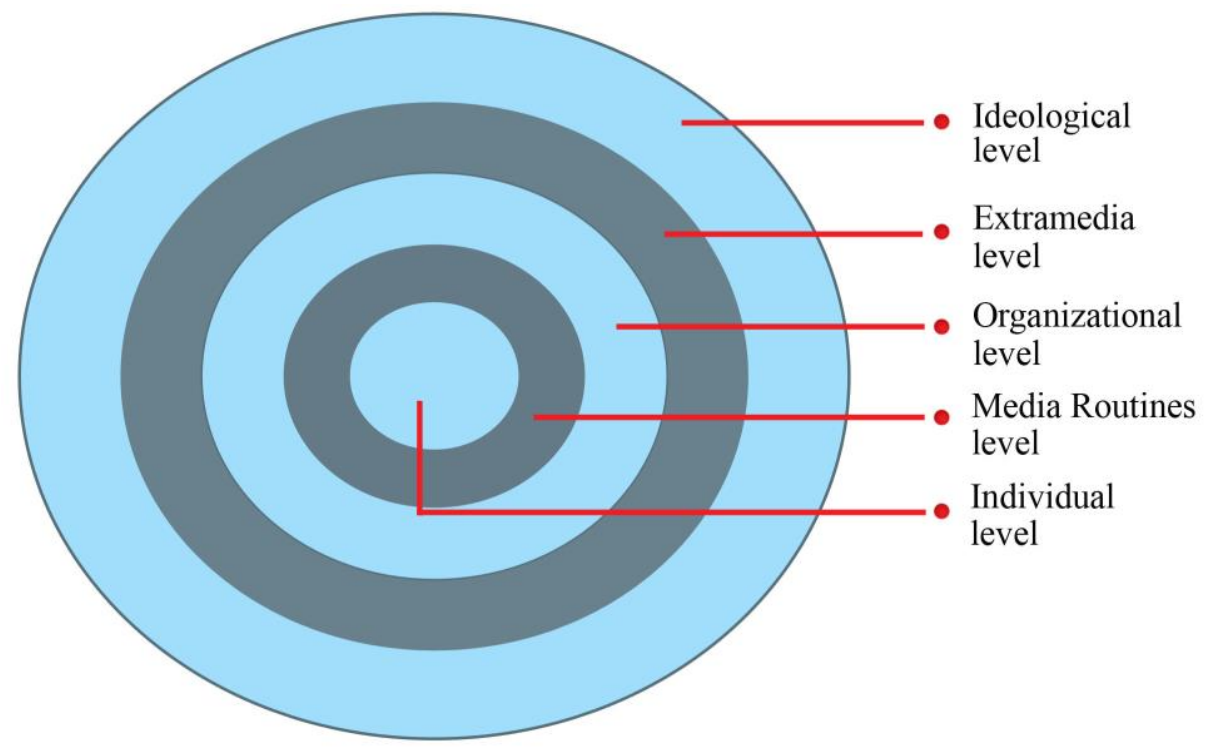

Gambar 1. Hierarki Pengaruh Pemberitaan Media Sumber: Shoemaker and Reese (1996: 223)

1. Level individual, berhubungan dengan latar belakang professional dari pengelola media.

2. Level rutinitas media, berhubungan dengan mekanisme dan proses penentuan berita.

3. Level organisasi, berhubungan dengan struktur organisasi yang secara hipotetik memengaruhi pemberitaan.

4. Level ekstramedia, berhubungan dengan lingkungan di luar media, antara lain:

a. Sumber berita, yang di sini dipandang bukan sebagai pihak yang netral, tetapi juga memiliki kepentingan untuk memengaruhi media dengan berbagai alasan, misalnya memenangkan opini publik, memberi citra tertentu kepada khalayak, dsb.

b. Sumber penghasilan media, berupa pemasang iklan, penanam modal, dll. Media harus survive, untuk itu kadangkala media harus berkompromi dengan pihak-pihak dan pelbagai sumber daya yang menghidupi mereka. 
Vol 1 No. 1, 2018, 15-48

DOI: https://doi.org/10.30596/persepsi.v1i1.2504

c. Pihak eksternal, seperti pemerintah dan lingkungan bisnis.

5. Level ideologi, yang diartikan sebagai kerangka berpikir atau kerangka referensi individu dalam menafsirkan realitas dan bagaimana mereka menghadapinya (Yusuf, 2011: 311).

Kebijakan editorial kerap juga diartikan sebagai ketentuan yang disepakati oleh redaksi media massa tentang kriteria berita atau tulisan yang boleh atau tidak boleh dipublikasikan sesuai visi - misi media dan pengaruh lima faktor tersebut. Shoemaker dan Reese (dalam SeverinTankard, 2005: 278) menyebut lima faktor tersebut sebagai "hierarki pengaruh".

Haris (2006: 23) mengatakan kebijakan redaksional lebih memusatkan perhatian kepada bagaimana aspek-aspek dan misi ideal yang dijabarkan dalam peliputan dan penempatan berita, laporan, tulisan, dan gambar yang sesuai dengan kepentingan dan selera khalayak.

Dapat disimpulkan kebijakan editorial merupakan pedoman (baik tertulis maupun tidak tertulis) bagi redaksi dalam mengelola newsroom, mulai dari menentukan isi liputan, angle liputan, memilih narasumber, penugasan, model tulisan dan sebagainya. Tegasnya, kebijakan editorial merupakan kaidah bagi setiap langkah operasional pemberitaan yang mengacu kepada segmentasi pembaca tertentu dan sikap dasar suratkabar sebagai dasar menetapkan visi misinya, selain mempertimbangkan beberapa faktor lain dalam "hierarki pengaruh" dari Shoemaker dan Reese.

\section{Kebijakan Editorial sebagai Agenda Setting Media}

Teori agenda setting dilahirkan oleh Maxwell McComb dan Donald L.Shaw untuk melihat kesesuaian agenda media massa dalam menentukan isu pemberitaan dengan kebutuhan masyarakat terhadap informasi (Rakhmat, 1992:

226-227). Pamela J Shoemaker mengatakan agenda setting terjadi karena media massa sebagai penjaga gawang informasi (gatekeeper) harus selektif dalam menyampaikan berita. Media harus melakukan pilihan mengenai apa yang harus dilaporkan dan bagaimana melaporkannya. Apa yang diketahui publik mengenai suatu keadaan pada waktu tertentu sebagian besar ditentukan oleh proses penyaringan dan pemilihan berita yang dilakukan oleh media massa (Morissan, 2013: 496).

Morissan (2013: 495) mengemukakan sebenarnya Walter Lippmann, seorang komentator dan penulis kolom terkenal di AS, adalah orang pertama yang mengemukakan gagasan agenda setting. Lippmann mengemukakan media bertindak sebagai perantara antara dunia luar dan gambaran di kepala kita (masyarakat), karenanya media bertanggungjawab membentuk persepsi publik terhadap dunia.

Gagasan Lippman itu kemudian dikembangkan oleh Donald Shaw dan Maxwell McComb dengan menyatakan para editor dan para pengelola media penyiaran memainkan peran penting dalam membentuk realitas sosial ketika mereka melakukan pekerjaan untuk memilih dan membuat berita. Dampak dari media massa yaitu kemampuannya untuk memengaruhi perubahan kognitif individu, untuk membentuk pemikiran mereka dinamakan dengan fungsi agenda setting komunikasi massa. Di sinilah letak efek paling penting komunikasi massa, yaitu kemampuannya secara mental untuk menata dan mengorganisasi dunia kita untuk kita (Morissan, 2013: 496).

Rakhmat (1992: 260) menegaskan teori agenda setting dimulai dengan suatu asumsi bahwa media massa menyaring berita, artikel, atau tulisan yang akan disiarkannya. Secara selektif gatekeepers seperti penyunting, redaksi, bahkan wartawan sendiri menentukan mana yang pantas diberitakan dan mana yang yang harus disembunyikan.

Dalam hal ini agenda setting dapat dibagi ke dalam dua tingkatan (level). Agenda setting level pertama adalah upaya membangun isu umum yang dinilai penting, dan level kedua adalah menentukan bagian-bagian atau aspek-aspek dari isu umum tersebut yang dinilai penting (Morissan, 2013: 496-497). Jorgensen dan Hanitzsch (2009: 154) mengatakan hasil penelitian agenda setting menyebutkan bahwa para wartawan dan redaktur di media massa memiliki kekuasaan besar untuk menentukan topik utama dalam pemberitaan yang disajikan kepada masyarakat.

Uraian tersebut dapat disimpulkan bahwa kebijakan editorial penting untuk mendukung agenda setting media massa. Pengelola suratkabar menyusun kebijakan editorial supaya pemberitaannya bisa memenuhi kebutuhan masyarakat yang menjadi segmentasi pembacanya 
Vol 1 No. 1, 2018, 15-48

DOI: https://doi.org/10.30596/persepsi.v1i1.2504

terhadap informasi tertentu. Kebijakan editorial ini menjadi pedoman bagi wartawan dan redaktur dalam menentukan arah pemberitaannya sekaligus menunjukkan karakter suratkabar tersebut. Setiap peliputan dan penempatan berita harus dapat menjabarkan aspek-aspek dan misi ideal dalam kebijakan editorial tersebut agar sesuai kebutuhan dan selera khalayak pembaca.

\section{Berita Produk Suratkabar}

Kekuatan dan daya tarik media cetak di mata pembaca terletak pada berita dan informasi yang disajikan (Fink, 1998: 136). Suratkabar sebagai media cetak memproduksi berita dari kegiatan jurnalistik yang dilakukan oleh para wartawan. Effendy (2005: 13) menjelaskan jurnalistik adalah suatu pengelolaan laporan harian yang menarik minat khalayak mulai dari peliputan sampai penyebarannya kepada masyarakat.

Sedangkan berita, menurut Mitchel V. Charnley (dalam Effendy, 2005: 131) adalah laporan tercepat mengenai fakta atau opini yang mengandung hal yang menarik minat atau penting, atau kedua-duanya, bagi sejumlah besar penduduk. George C. Bastian (dalam Feliza, 1982: 24) menyebutkan berita adalah rekaman berbagai hal penting yang menarik dan informasi akurat yang dapat diperoleh untuk mengetahui hal-hal yang dipikirkan dan dikatakan, dilihat dan digambarkan, direncanakan dan dilakukan orang.

Ahli lain Rachmadi (1988: 23) menyebutkan berita sebagai laporan peristiwa atau kejadian fakta dan diperoleh secara jujur dan dapat dipertanggungjawabkan. Selain itu William S. Mauslby (dalam Pareno, 2003: 43) mendefinisikan berita sebagai suatu penuturan secara benar dan tidak memihak dari fakta-fakta yang mempunyai arti penting dan baru terjadi, yang dapat menarik perhatian para pembaca berita di suratkabar tersebut (Pareno, 2003: 43).

Kesimpulannya, berita adalah laporan peristiwa atau fakta yang baru terjadi, penting, dan menarik perhatian masyarakat sebagai pembaca suratkabar, memuat hal-hal yang dipikirkan dan dikatakan, dilihat dan digambarkan, direncanakan dan dilakukan orang. Semua diperoleh secara jujur dan dapat dipertanggungjawabkan.

Setiap peristiwa yang memenuhi syarat berita akan lebih berbobot apabila memiliki nilai berita. Brooks dkk. ( 1988: 4) menyebutkan nilai berita tersebut adalah impact (segala sesuatu yang berdampak luas), proximity (jarak atau kedekatan peristiwa secara geografis maupun psikologis dengan masyarakat yang menjadi audiens media massa), timeliness ( peristiwa yang sedang atau baru terjadi), prominence (seseorang atau sesuatu yang terkenal), novelty (sesuatu yang luar biasa), dan conflict (segala sesuatu yang mengandung unsur pertentangan).

Selain itu, menurut Kusumaningrat (2005:48), terdapat tujuh sifat istimewa berita yang disebut juga sebagai unsur layak berita yaitu akurat, lengkap, adil dan berimbang, objektif, ringkas, jelas, dan hangat.

Berdasarkan klasifikasinya berita tersebut dapat dibagi menjadi dua, yaitu berita berat (hardnews) dan berita ringan (softnews) (Sumadiria, 2006:65). Sedangkan berdasarkan jenisnya berita dibedakan menjadi straight news, investigative news, explanatory news, interpretative news, depth news, feature (Kamal, 2009: 27).

Jenis-jenis berita itu dapat dijelaskan sebagai berikut:

1. Straight news (berita langsung) yaitu berita yang informasinya diperoleh langsung dari narasumber. Biasanya diungkap dalam bentuk pemaparan dan penulisannya mengutamakan aktualitas informasi.

2. Investigative news (penggalian berita) yaitu berita yang dikembangkan berdasarkan penelitian (penyelidikan) dari berbagai sumber. Berita bermula dari adanya isu (data mentah). Penulisannya memusatkan pada sejumlah masalah (kontroversi).

3. Explanatory news (pengungkapan berita) yaitu berita menjelaskan, artinya data yang disajikan lebih banyak diuraikan daripada diungkap secara langsung, penulisannya bisa dipadukan antara fakta dan opini (argumentasi).

4. Interpretative news (penjelasan berita) yaitu berita yang penyajiannya gabungan dari fakta dan interpretasi, penulis boleh memasukkan uraian (komentar) yang ada kaitannya dengan data yang diperolehnya dari peristiwa yang diliputnya. 
Vol 1 No. 1, 2018, 15-48

DOI: https://doi.org/10.30596/persepsi.v1i1.2504

5. Depth news (berita pendalaman) yaitu berita yang penulisannya bersifat mendalam, tajam, lengkap, dan utuh tentang peristiwa fenomenal (aktual), dan berita berasal dari adanya sebuah berita yang belum selesai pengungkapnnya dan dilanjutkan kembali.

6. Feature (karangan khas) yaitu berita yang penulisan dan penyajiannya menggunakan teknik mengisahkan dalam bentuk naratif berdasarkan fakta, dan penulisannya lebih bergantung pada gaya bahasa yang ringan dan menghibur.

Berdasarkan materi isinya berita dapat dikelompokkan ke dalam: 1. Berita pernyataan pendapat, idea tau gagasan (talking news), 2. Berita ekonomi (economic news), 3. Berita keuangan (financial news), 4. Berita politik (political news), 5. Berita sosial kemasyarakatan (social news), 6. Berita pendidikan (education news), 7. Berita hukum dan keadilan (law and justice news), 8. Berita olahraga (sport news), 9.Berita kriminal (crime news), 10. Berita bencana dan tragedi (tragedy and disaster news), 11. Berita perang (war news), 12. Berita ilmiah (scientific news), 13. Berita hiburan (entertainment news), 14. Berita tentang aspek-aspek ketertarikan manusiawi atau minat insane (human interest news) (Sumadiria: 2006: 67)

Setiap berita, menurut Walter Lippmann, berfungsi sebagai sinyal bagi suatu peristiwa (DeFleur and Dennis, 1985: 443). Sinyal tersebut memudahkan orang untuk mengetahui peristiwa itu. Maka orang dapat melakukan apa yang disebut Harorld D. Laswell sebagai "surveillance" atau mengamati lingkungan untuk menemukan apa yang terjadi (Susanto, 1977: 46). Secara lengkap Laswell (dalam Severin-Tankard: 2005: 386) mengemukakan pada prinsipnya ada tiga fungsi berita dalam suratkabar atau media massa : pengamatan lingkungan, korelasi bagian-bagian dalam masyarakat untuk merespon lingkungan, dan penyampaian warisan masyarakat dari satu generasi ke generasi selanjutnya. Selain itu, Severin - Tankard (2005: 386) mengemukakan, C Wright menambahkan fungsi keempat, yaitu hiburan.

Wilbur Schramm melengkapi fungsi media massa sebagai pembawa berita sebagai berikut:

1. Informasi

Yaitu menyampaikan peristiwa yang terjadi, ucapan atau pikiran orang lain, dan sebagainya.

2. Pendidikan

Sebagai sarana pendidikan media massa memuat berita-berita yang mengandung pengetahuan.

3. Mengisi waktu terluang (menghibur)

Berita-berita bersifat hiburan dimuat oleh media massa untuk mengimbangi berita berat (hard news) agar khalayak merasa terhibur.

4. Mempengaruhi

Secara implisit fungsi ini terdapat pada berita, sedangkan secara eksplisit pada tajuk rencana atau artikel. Untuk bidang perniagaan terdapat dalam iklan-iklan. Tujuan fungsi ini agar khalayak terpengaruh dan mengikuti apa yang diinginkan oleh komunikator (Susanto, 1977: 45).

Dengan demikian berita yang berfungsi sebagai sinyal bagi peristiwa akan membantu masyarakat pembaca suratkabar melakukan pengamatan (surveillance) terhadap lingkungan, perangkaian (correlation) informasi, dan penyaluran (transmission) warisan sosial. Atau secara lebih sederhana dapat dikatakan bahwa berita memiliki fungsi sebagai informasi, pendidikan, menghibur, dan memengaruhi baik secara kognitif, afektif, atau konatif terhadap masyarakat.

Sumadiria (2006: 67-68) mengemukakan pengetahuan dan pemahaman tentang berita sangat penting bagi setiap reporter, editor, dan bahkan para perencana dan konsultan media (media planner) sebagai salah satu pijakan dasar dalam proses perencanaan (planning), peliputan (getting), penulisan (writing), dan pelaporan serta pemuatan, penyiaran, dan penayangan berita (reporting and publisihing). Pada akhirnya tahapan-tahapan pekerjaan jurnalistik itu sangat diperlukan dalam kerangka pembentukan, penetapan, dan pengembangan manajemen media massa (mass media management) secara profesional dan visioner.

\section{Pemberitaan Ekonomi dan Bisnis di Suratkabar}


Vol 1 No. 1, 2018, 15-48

DOI: https://doi.org/10.30596/persepsi.v1i1.2504

Assegaf (1985: 38-39) menggolongkan berita ekonomi sebagai salah satu macam berita berdasarkan soal atau masalah yang dicakup berita tersebut, sebagaimana berita politik, olahraga, ilmu pengetahuan, pendidikan, agama, dan lain sebagainya. Suratkabar yang ingin maju, menurut Assegaf (1985: 43), haruslah memperhatikan pemberitaan ekonomi, karena menyangkut segi hayati manusia, yakni usaha mencari nafkah untuk memenuhi kebutuhan hidupnya.

James L.C. Ford dalam tulisan berjudul Covering the Bussiness menyebutkan pria dan wanita seluruhnya dicengkeram oleh kesibukan pekerjaan mencari nafkah. Berita-berita ekonomi adalah pencaharian aspek-aspek yang terorganisir dari pekerjaan tersebut, yaitu berita bagaimana orang mencari nafkah hidupnya sehari-hari. Meskipun demikian seluruh aspek-aspek praktis maupun materialistisnya, semuanya penuh dengan ketegangan dan emosi dari perjuangan manusia setiap hari untuk meneruskan hidupnya (Assegaf: 1985: 42).

Suratkabar dalam beberapa tahun terakhir memang sudah cenderung memperioritaskan pemberitaan masalah ekonomi dan bisnis tersebut, baik secara kuantitas maupun kualitas. Masalah perekonomian dan bisnis dianggap sebagai berita besar, disamping masalah politik. Beritaberitanya seringkali menghiasi halaman depan, selain itu hampir setiap suratkabar mempunyai halaman atau rubrik ekonomi dan bisnis. Bahkan sejumlah suratkabar muncul sebagai suratkabar khusus memberitakan masalah perekonomian dan bisnis.

Assegaf (1985: 42-43) mengakui kebutuhan berita-berita ekonomi telah mendorong timbulnya harian-harian khusus yang hanya menyiarkan berita-berita ekonomi, misalnya harian Wall Street Journal di Amerika Serikat atau majalah mingguan The Economist di Inggeris; atau di Indonesia seperti Bulletin Bussiness News dan Jurnal Ekonomi dahulu. Suratkabar dan majalah ekonomi ini mendapat perhatian utama dari kalangan dagang dan usahawan, apalagi pemberitaan ekonominya terkenal baik dan bermutu.

Brooks dkk. (1988: 306) mengemukakan kebutuhan terhadap pemberitaan ekonomi dan bisnis meningkat karena adanya kesadaran betapa permasalahan ini berhubungan erat dengan kebijakan politik dalam kehidupan sehari-hari. Misalnya,

inflasi memengaruhi keputusan politik di bidang perpajakan sehingga berpengaruh pula terhadap pengeluaran seorang warga, desentralisasi pemerintahan atau otonomi daerah membuat potensi ekonomi suatu daerah menjadi terangkat, begitu pula kerjasama internasional dapat memengaruhi tarif atau bea masuk ke suatu negara sehingga berdampak pada ekspor-impor, harga barang, dan lowongan pekerjaan.

Dengan demikian dapat disimpulkan semua permasalahan bisa diangkat menjadi berita ekonomi bisnis dan hampir setiap berita ekonomi bisnis selalu berhubungan dengan masyarakat sebagai konsumen. Karena itu suratkabar memperbesar porsi pemberitaan permasalahan ini (Brooks dkk, 1988: 306-307).

Hemp (1991: 7-8) menegaskan pemberitaan masalah ekonomi dan bisnis sangat diperlukan di semua negara, bukan hanya di negara berkembang yang sedang giat membangun perekonomiannya, karena memengaruhi kehidupan setiap warga mulai bankir sampai orang yang membeli roti atau beras di pasar.

Khusus di negara yang sedang membangun, Alan Chlakey (Mustoffa, 1996: 18-17) mengatakan, wartawan tidak hanya memberikan fakta kehidupan ekonomi dan menfasirkan fakta tersebut, tetapi juga mempromosikan fakta-fakta itu untuk membuat pembaca sadar betapa serius masalah pembangunan, memikirkannya, dan membuka mata mereka terhadap kemungkinan pemecahannya.

Demikian pula di Indonesia sebagai negara berkembang, apalagi setelah pemerintah memberlakukan kebijakan otonomi daerah. Warief Djajanto Basorie (Mustoffa, 1996: 15-16) mengemukakan pemerintah di Indonesia sudah menetapkan kebijakan memberi otonomi daerah sejak 1974, karena itu jurnalisme dapat ikut berperan mengembangkan daerah dengan melaporkan tentang kegiatan berpotensi ekonomi dan menunjukkan bagaimana masyarakat memperoleh manfaat darinya.

Dapat dikemukakan bahwa permasalahan ekonomi dan bisnis selalu berhubungan dengan manusia, bisa membawa perubahan ekonomi seseorang di 
Vol 1 No. 1, 2018, 15-48

DOI: https://doi.org/10.30596/persepsi.v1i1.2504

suatu daerah dalam negara tertentu yang notabene akan mengubah perekonomian daerah dan negara itu pula. Karena itu, menurut Hemp (1991: 9), masalah perekonomian dan bisnis penuh dengan drama kemanusiaan, seperti kesuksesan, kegagalan, dan rivalitas atau kompetisi satu dengan lainnya.

Suratkabar perlu menyajikan pemberitaan mengenai perekonomian dan bisnis tersebut dengan cara mudah dimengerti (understandable) supaya menarik perhatian (interesting) masyarakat yang menjadi pembacanya. Selama ini banyak pemberitaan masalah ini sulit dimengerti (complicated) dan membosankan (boring) bagi pembaca karena terlalu banyak jargon ekonomi, angka-angka dan statistik, wartawan lupa mengungkap pengaruh jargon dan angka-angka statistik tersebut terhadap manusia (Hemp, $1991: 8-9)$.

Assegaf (1985: 43) mengakui pencarian berita ekonomi menghendaki keahlian yang khas, misalnya saja untuk mendapatkan dan menuliskan berita sekitar perkembangan moneter, si wartawan sekurang-kurangnya dapat membaca "neraca singkat Bank Indonesia". Untuk itu diperlukan pengetahuan ekonomi dan moneter.

Berita ekonomi dan bisnis memang berbeda dari berita sepakbola misalnya, karena membutuhkan pengetahuan dan juga kemampuan berbahasa dari wartawan supaya dapat mengajukan pertanyaan dengan baik, menyadari nilai berita dari semua jawaban (narasumber), dan menuliskannyan sehingga pembaca tanpa pengetahuan khusus sekalipun bisa memahaminya. Soalnya, hanya wartawan yang memahami masalah tersebut yang mampu menjelaskan maksud berbagai jargon ekonomi dan bisnis (Brooks dkk., 1988: 308).

Warief Djajanto Basorie (Mustoffa, 1996: 16) mengemukakan semua upaya jurnalisme itu dalam menyuarakan kemauan masyarakat, mengemukakan sektor

maju, menyoroti ihwal bermasalah, dan membeberkan potensi daerah, bertujuan memotivasi pemerintah, swasta dan masyarakat untuk bertindak agar daerah yang bersangkutan lebih maju dan lebih mandiri sehingga mampu mengurus rumah tangganya sendiri.

\section{Kerangka Pemikiran}

Berdasarkan uraian Kerangka Teori di atas dapat digambarkan kerangka pemikiran dalam studi ini sebagai berikut.

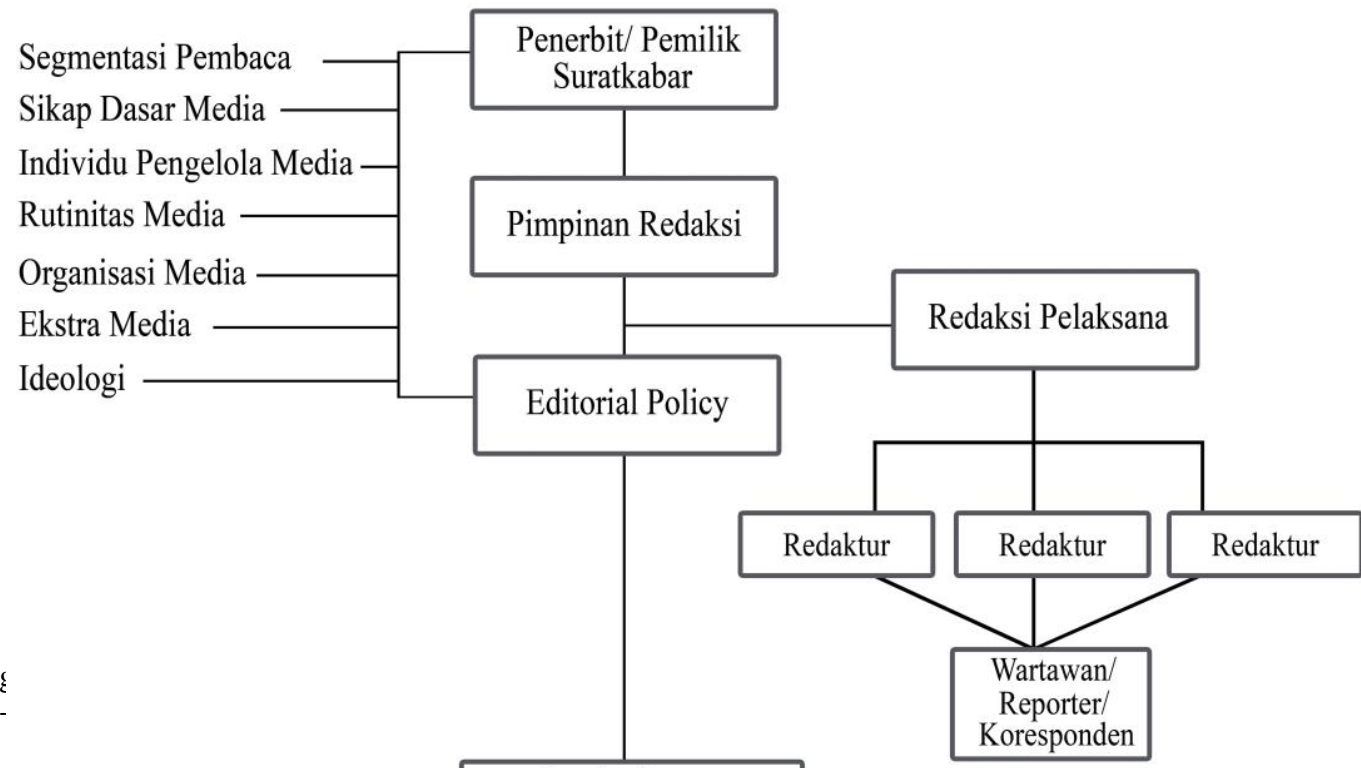




\section{Metode}

Metodologi dalam penelitian ini menggunakan pendekatan kualitatif. Bagdan dan Taylor (Moleong, 2004: 4) mengemukakan penelitian kualitatif adalah sebagai prosedur penelitian yang menghasilkan data deskriptif berupa kata-kata tertulis atau lisan dari orangorang dan perilaku yang diamati. Pendekatan ini diarahkan pada latar dan individu tersebut secara holistik (utuh). Dalam hal ini tidak boleh mengisolasikan individu atau organisasi ke dalam variable atau hipotetis tetapi perlu memandangnya sebagai bagian dari suatu keutuhan.

Kriyantono (2006: 58) mengatakan riset kualitatif bertujuan untuk menjelaskan fenomena dengan sedalam-dalamnya melalui pengumpulan data sedalam-dalamnya. Penelitian ini tidak mengutamakan besarnya populasi atau samplingnya sangat terbatas. Jika data terkumpul sudah mendalam dan bisa menjelaskan fenomena yang diteliti maka tidak perlu mencari sampling lainnya. Di sini yang lebih ditekankan adalah persoalan kedalaman (kualitas) data, bukan banyaknya (kuantitas) data.

Pendekatan kualitatif dalam penelitian ini bersifat deskriptif. Isaac dan Michael (Rakhmat , 2007: 24) mengatakan penelitian deskriptif memaparkan situasi atau peristiwa. Penelitian ini tidak mencari atau menjelaskan hubungan, tidak menguji hipotesis atau membuat prediksi. Arikunto (1998: 3) menambahkan penelitian deskriptif bertujuan menggambarkan secara sistematis dan akurat, fakta dan karakteristik mengenai populasi atau bidang tertentu.

\section{Unit Analisis}

Unit analisis pada penelitian ini adalah seluruh proses dan faktor-faktor yang membentuk kebijakan editorial suratkabar Harian MedanBisnis dalam pemberitaan masalah ekonomi dan bisnis. Pengamatan terhadap pemberitaan masalah itu beserta wawancara pendahuluan dengan pimpinan redaksi dan redaktur sebagai informan dapat dianggap memadai untuk mengidentifikasi bentuk kebijakan editorial dalam pemberitaan suratkabat tersebut.

Peneliti melakukan analisis triangulasi untuk menguji kebenaran dan kejujuran informan sebagai subjek dalam penelitian ini. Kriyantono (2006: 71) mengemukakan analisis triangulasi yaitu menganalisis jawaban subjek dengan meneliti kebenarannya dengan data empiris (sumber data lainnya) yang tersedia. Di sini jawaban subjek di cross-check dengan dokumen yang ada.

\section{Lokasi dan Waktu Penelitian}

Penelitian ini dilaksanakan di kantor redaksi suratkabar Harian MedanBisnis Jalan S. Parman No. 5-7 Medan. Waktu penelitian dilakukan selama Maret-Desember 2014, mulai dari pra riset hingga riset rampung. 


\section{Hasil dan Pembahasan}

Saat pertama kali terbit pada 15 Januari 2001 di Kota Medan, MedanBisnis merupakan suratkabar mingguan yang memberitakan masalah perekonomian dan bisnis. Suratkabar yang diterbitkan oleh perusahaan berbadan hukum PT Kasih Karunia MedanBisnis ini didirikan untuk menggarap pemberitaan ekonomi dan bisnis karena suratkabar yang ada di Kota Medan cenderung mengutamakan pemberitaan politik, kriminal, masalah perkotaan, dan pemberitaan umum lainnya. Maka MedanBisnis menjadi suratkabar pertama yang khusus menyajikan pemberitaan ekonomi dan bisnis di Kota Medan, bahkan Sumatera Utara.

Bambang Sulaksono, mantan pemimpin redaksi yang kini menjadi redaktur senior, mengatakan pilihan pendiri MedanBisnis menggarap pemberitaan ekonomi dan bisnis juga karena ada pertimbangan jika ikut-ikutan memberitakan permasalahan umum akan sulit bersaing dengan suratkabar umum yang sudah lama terbit, seperti Harian Waspada, Sinar Indonesia Baru, dan Analisa. Suratkabar-suratkabar umum ini sudah mendapat tempat di hati masyarakat Medan, bahkan Sumatera Utara dan Aceh sehingga sulit menggesernya (Wawancara Bambang Sulaksono, 18 November 2014).

Dalam perkembangannya, masyarakat Kota Medan dan daerah-daerah di Sumatera Utara memberi respon positif terhadap MedanBisnis, karena itu enam bulan kemudian suratkabar mingguan ini terbit sebagai harian, persisnya pada 31 Juli 2001.

Masa awal sebagai suratkabar harian, MedanBisnis terbit 16 halaman setiap hari. Pengelola suratkabar ini menerapkan komposisi berimbang dalam penyajian beritanya, dimana 50\% dari 16 halaman untuk pemberitaan ekonomi dan bisnis serta 50\% lagi untuk berita umum. Kebijakan ini bertujuan agar di samping berita-berita ekonomi dan bisnis sebagai menu utama, para pembaca juga bisa menikmati berita umum, mulai persoalan politik, kriminal, hukum, sampai human interest dalam satu suratkabar.

Pemimpin redaksi baru Bersihar Lubis didampingi oleh Sarsin Siregar sebagai wakil pemimpin redaksi, sedangkan untuk redaktur pelaksana ditunjuk Nurhalim Tanjung. Tak lama kemudian ada penunjukan Paul Kusuma sebagai wakil pemimpin umum, persisnya pada November 2008. Paul Kusuma adalah putra kandung Supandi Kusuma sehingga menjadi representasi langsung pemilik suratkabar ini.

Struktur pengelola redaksi baru ini membuat terobosan dengan mengubah format Harian MedanBisnis dari sembilan kolom menjadi tujuh kolom sejak 11 November 2012 sebagaimana penampilan suratkabar modern dewasa ini. Selain itu dilakukan pula penambahan empat halaman lagi sehingga suratkabar ini terbit 28 halaman, dimana pemberitaan ekonomi dan bisnis semakin diperkuat dengan menyediakan 16 halaman, sedangkan 12 halaman lagi untuk berita umum. 


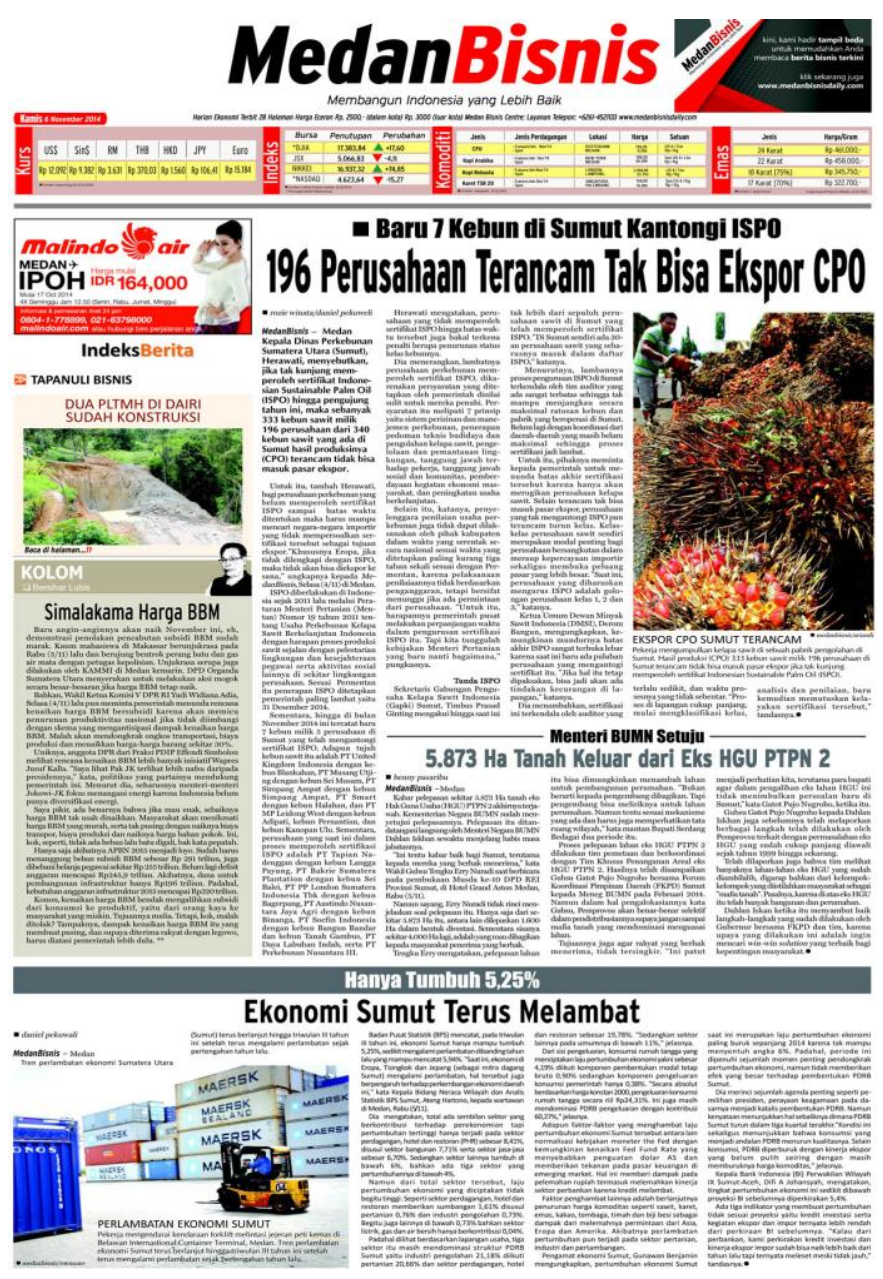

Gambar 3. Harian MedanBisnis Format 7 Kolom Sumber: MedanBisnis Edisi 6 November 2014

Pemimpin Redaksi Bersihar Lubis mengemukakan meski Harian MedanBisnis memiliki dua bagian dalam pemberitaannya, tetapi berita-berita bagian umum masih menyinggung ekonomi atau berkaitan dengan ekonomi dan bisnis. Misalnya, berita hukum dipilih mengenai kasus kejahatan kerah putih yang melibatkan eksekutif di pemerintahan maupun swasta, berita politik bisa tentang konflik di legislatif dalam menentukan kenaikan harga bahan bakar minyak (BBM)atau berita tentang bencana alam dilihat dampaknya terhadap kegiatan perekonomian masyarakat yang menjadi korban (Wawancara Bersihar Lubis, 26 Oktober 2014).

Harian MedanBisnis juga tampil full-colour setiap hari. Semua perkembangan itu menunjukkan tekad pengelola Harian MedanBisnis untuk menjadi suratkabar yang berbeda di Kota Medan dan Sumatera Utara. Pemimpin Umum Paulus M. Tjukrono (dalam Profile MedanBisnis, 2013) mengemukakan memiliki satu tekad yaitu suratkabar ini harus memiliki perbedaan dengan koran-koran yang telah ada di Medan untuk bisa menerobos pasar.

Perbedaan tersebut antara lain menyangkut aspek pemberitaan sebagai menu utama suratkabar, dengan menyajikan berita-berita aktual, menarik, bisa dipercaya, dan eksklusif. Semua berita itu dikemas dalam bahasa yang benar dengan cara penyajian sepopuler mungkin.

Hemp (1991: 8) mengatakan suratkabar memang perlu menyajikan pemberitaan mengenai perekonomian dan bisnis dengan cara mudah dimengerti (understandable) supaya menarik perhatian (interesting) masyarakat yang menjadi pembacanya. John Tafbu Ritonga (dalam Economic for Journalist, 2011) mengemukakan pula reporter suratkabar ekonomi harus bisa 
Vol 1 No. 1, 2018, 15-48

DOI: https://doi.org/10.30596/persepsi.v1i1.2504

menyajikan berita ekonomi secara renyah dan mampu mengedukasi masyarakat untuk memahami masalah perekonomian secara baik.

\section{Rubrikasi MedanBisnis}

Kebijakan menyajikan dua komposisi atau dua bagian dalam pemberitaan Harian MedanBisnis membuat pengelola redaksi suratkabar ini memiliki rubrikasi untuk berita ekonomi dan bisnis serta berita umum. Beberapa rubrik yang ada menunjukkan Harian MedanBisnis merupakan suratkabar ekonomi lokal dengan memprioritaskan pemberitaan sektor ekonomi dan bisnis berskala mikro. Rubrikasi itu antara lain Tapanuli Bisnis dan Aceh Bisnis untuk menunjukkan suratkabar ini memperhatikan perekonomian dan bisnis lokal, sedangkan rubrik Agribisnis, UKM, Infrastruktur \& Properti, serta Bursa menunjukkan perhatian terhadap kegiatan perekonomian dan bisnis berskala mikro.

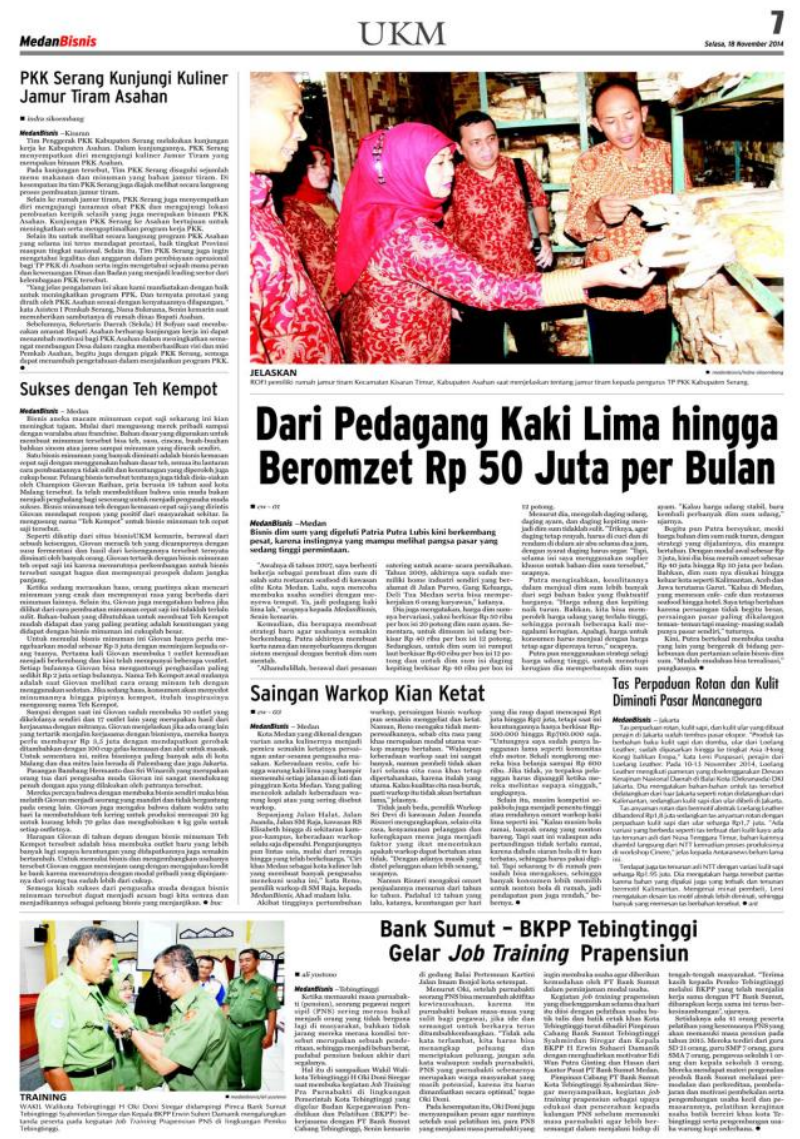

Gambar 4: Rubrik UKM Harian MedanBisnis

Sumber: MedanBisnis Edisi 18 November 2014 
Vol 1 No. 1, 2018, 15-48

DOI: https://doi.org/10.30596/persepsi.v1i1.2504

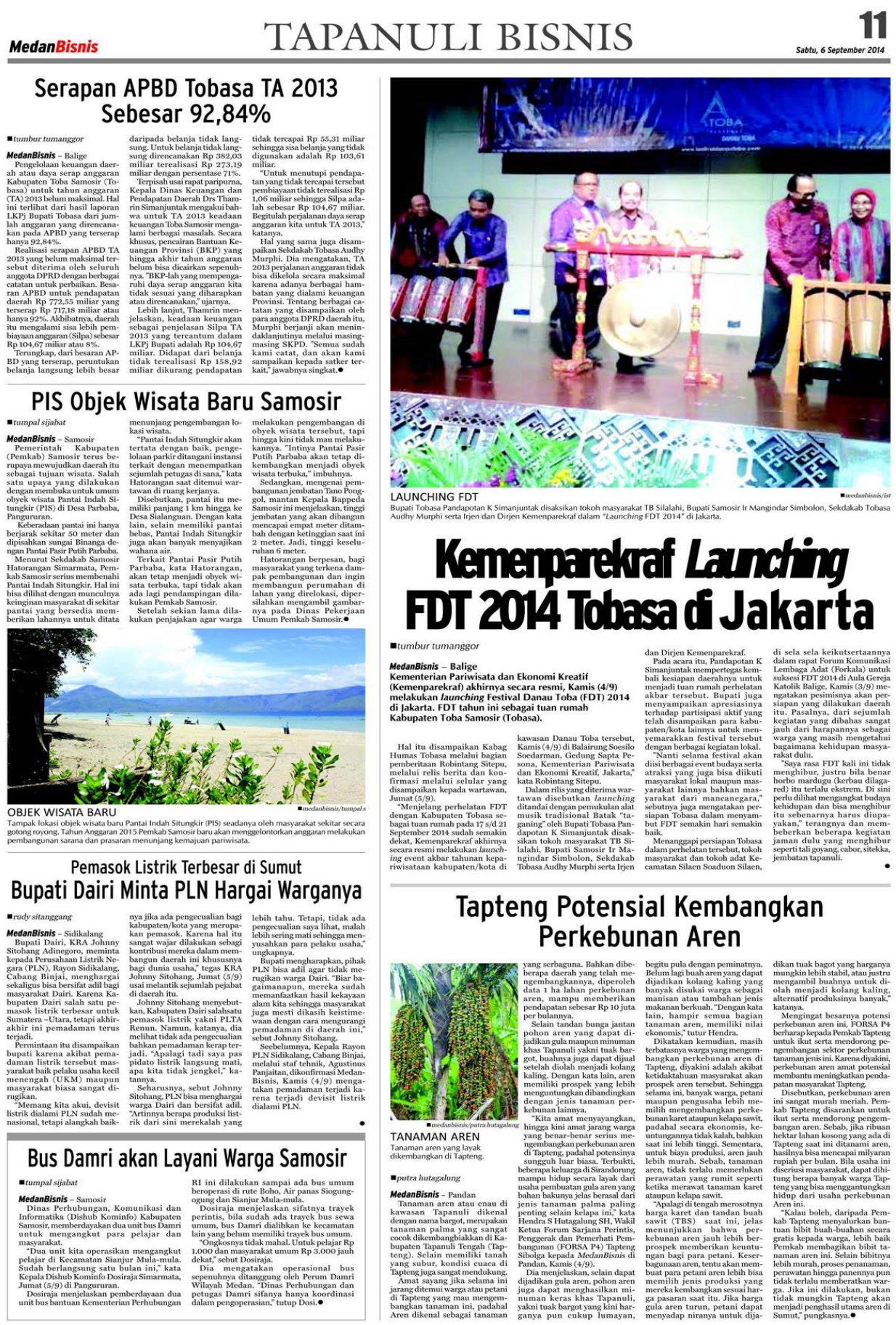

Gambar 5: Rubrik Tapanuli Bisnis Harian MedanBisnis Sumber: MedanBisnis Edisi 6 September 2014

Perhatian Harian MedanBisnis terhadap berita ekonomi dan bisnis juga tampak dari perbandingan rubrikasinya dengan berita nonekonomi. Rubrikasi ekonomi dan bisnis hampir mencapai 57,143\% atau 16 halaman dari 28 halaman suratkabar ini, sedangkan 42,857\% lagi atau 12 halaman merupakan porsi rubrikasi untuk berita umum atau nonekonomi.

Tabel 1. Rubrikasi Harian MedanBisnis 
Vol 1 No. 1, 2018, 15-48

DOI: https://doi.org/10.30596/persepsi.v1i1.2504

\begin{tabular}{|c|c|c|c|}
\hline Hal & RUBRIK EKONOMI & Hal & RUBRIK UMUM \\
\hline 1 & Ekonomi I & 1 & Berita Umum \\
\hline 2 & Wacana & II & Politik \\
\hline 3 & Industri & III & Hukum \\
\hline 4 & Agri Bisnis & IV & Metropolitan \\
\hline 5 & Perdagangan & $\mathrm{V}$ & Internasional \\
\hline 6 & Infrastruktur dan Properti & $\mathrm{VI}$ & Daerah \\
\hline 7 & $\begin{array}{ll}- & \text { UKM } \\
\text { - } & \text { Informasi dan } \\
& \text { Teknologi } \\
- & \text { Otomotif }\end{array}$ & VII & Daerah \\
\hline 8 & Keuangan dan Perbankan & VIII & Olahraga \\
\hline 9 & Bursa & IX & Olahraga \\
\hline 10 & Interaktif Bisnis & $x$ & Daerah \\
\hline 11 & Tapanuli Bisnis & $\mathrm{XI}$ & Daerah \\
\hline 12 & Aceh Bisnis & XII & Nasional \\
\hline 13 & Aceh Bisnis & - & - \\
\hline 14 & Ekonomi Dunia & - & - \\
\hline 15 & Showbiz & - & - \\
\hline 16 & Ekonomi & - & - \\
\hline
\end{tabular}

\begin{tabular}{ll}
\hline Total Rubrik Ekonomi & $: 16 \mathrm{Hal}$ \\
Total Rubrik Umum & $: 12 \mathrm{Hal}$ \\
Total Keseluruhan Halaman : $28 \mathrm{Hal}$
\end{tabular}

Sumber:MedanBisnis, diolah

Porsi rubrikasi di bagian ekonomi dan bisnis yang lebih banyak daripada bagian umum membuktikan Harian MedanBisnis memang memperkuat diri sebagai suratkabar ekonomi, selain ada pula kebijakan redaksi untuk memilih berita di bagian umum mesti berkaitan dengan ekonomi dan bisnis. Kebijakan pemberitaan ini semakin memperkuat posisi MedanBisnis sebagai suratkabar ekonomi.

Setiap rubrik atau halaman Harian MedanBisnis dikelola oleh redaktur sebagai gate-keeper atau filter yang menjaga dan menyaring berita yang hendak disajikan. Djuroto (2004: 21-22) 
mengatakan redaktur bertanggungjawab terhadap isi halaman suratkabar, dimana tugasnya merencanakan, menerima, dan memilih berita yang layak untuk disajikan kepada pembaca.

Para redaktur Harian MedanBisnis dalam menunaikan tugasnya menggunakan perspektif ekonomi saat melihat setiap isu dan peristiwa di masyarakat. Perspektif itu diperlukan untuk mencermati isu ekonomi maupun isu nonekonomi yang berdampak terhadap kegiatan ekonomi dan bisnis. Kepekaan itu semakin dibutuhkan mengingat suratkabar ini sedang memperkuat posisi sebagai referensi ekonomi dan bisnis, khususnya di Sumatera Utara.

Rapat Kerja Redaksi Harian MedanBisnis pada 21-22 Januari 2011 menghasilkan rumusan sebagai panduan terhadap kandungan yang dibutuhkan dalam pemberitaan suratkabar ini. Adapun panduan untuk isi pemberitaan tersebut adalah:

1. Berita ekonomi lokal

2. Kegiatan perekonomian mikro (sektor riil)

3. Berita ekonomi nasional berdampak lokal

4. Kebijakan ekonomi makro berdampak lokal

5. Berita umum yang sesuai untuk pebisnis: misalnya, untuk kriminal mengenai kejahatan kerah putih, olahraga adalah golf, tenis dan sepakbola, sedangkan politik soal transaksi menggolkan atau membatalkan peraturan daerah (perda) dsb.

\section{Segmentasi Pembaca dan Arah Pemberitaan}

Manajemen Harian MedanBisnis membidik para pembaca dari kalangan menengah ke atas sebagai segmentasi pasar. Para pembaca tersebut memiliki profesi sebagai pebisnis, eksekutif, dan dan kaum profesi yang memiliki tingkat kehidupan mapan dan berdaya beli tinggi.

John Tafbu Ritonga (dalam Economic for Journalist, 2011) mengatakan Harian MedanBisnis memang harus fokus kepada pasar menengah ke atas sebab memang itulah pasar suratkabar ekonomi. Begitupun suratkabar ini tetap harus memberitakan persoalan ekonomi masyarakat bawah sebagai realita perekonomian yang juga perlu diketahui masyarakat kelas menengah dan atas yang menjadi segmentasi pembacanya.

Konsep dalam menyasar pembaca itu membuat Harian MedanBisnis mendapat image sebagai suratkabar elit. Kini suratkabar ini dilanggani para pengusaha, profesional, eksekutif, perusahaan-perusahaan besar di sektor penerbangan, perhotelan, konstruksi, industri, dan instansi pemerintahan sebagai pengambil kebijakan dalam bidang perekonomian (Profil MedanBisnis, 2013). Gambar berikut memperlihatkan komposisi pembaca Harian MedanBisnis berdasarkan profesi.

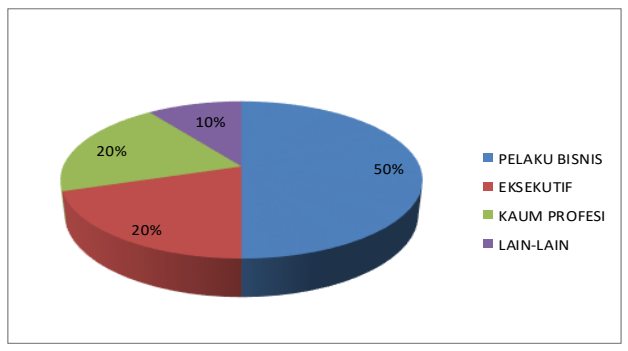

Gambar 6. Komposisi Pembaca Harian MedanBisnis Sumber: Profile MedanBisnis, 2013

Para pembaca Harian MedanBisnis mayoritas berada di Kota Medan, terbukti sekira 50\% dari tirasnya yang berjumlah sekitar 20.000 eksemplar per hari beredar di sini. Selebihnya beredar di daerah-daerah tingkat dua di Sumatera Utara, selain juga didistribusikan ke Aceh dan Jakarta. Komposisi pasar Harian MedanBisnis tersebut dapat dilihat dalam gambar yang menunjukkan daerah distribusinya di bawah ini. 


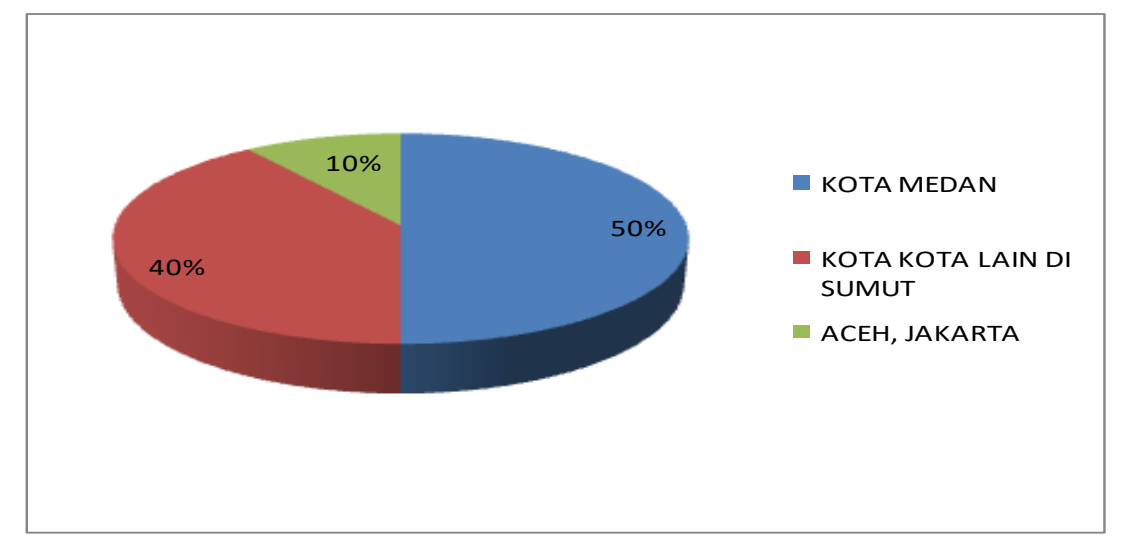

Gambar 7. Komposisi Pasar Harian MedanBisnis Sumber: Profil MedanBisnis, 2013

Komposisi pasar itu mempertegas Harian MedanBisnis sebagai suratkabar ekonomi lokal. Pemimpin Redaksi Bersihar Lubis mengakui sasaran MedanBisnis adalah pembaca lokal, yang tercermin dari orientasi pemberitaan suratkabar ini.

Sasaran dari MedanBisnis adalah pasar lokal sebagai suratkabar ekonomi dan bisnis lokal. Maka tentu berita ekonomi mikro dan lokal menjadi prioritas MedanBisnis, lagi pula kalau porsi nasional sudah diambil oleh koran-koran nasional bahkan juga dari visi nasional yang penyebarannya lebih cepat dan disampaikan berulang-ulang, jadi kita ambil ceruk peluang itu agar MedanBisnis bisa eksis, tetap bisa jadi sumber (informasi) bagi pembaca (lokal) (Wawancara Bersihar Lubis. 26 Oktober 2014).

Harian MedanBisnis sesungguhnya belum sepenuhnya mampu memenuhi sasarannya untuk menjangkau pasar lokal tersebut, padahal dalam Rapat Kerja Redaksi pada 21-22 Januari 2011 juga sudah disepakati untuk memperbesar pemberitaan ekonomi lokal dan berskala mikro, sebagaimana dikemukakan oleh Wakil Pemimpin Umum Paul Kusuma.

Kita berusaha perkuat pemberitaan dari daerah-daerah, kita minta wartawan mencari berita tentang kegiatan ekonomi lokal, sebab kalau kita mau bersaing sama Kompas atau Kontan (dengan membuat pola berita yang sama berskala nasional dan internasional) pasti kalah kita. Makanya saya mau wartawan-wartawan di daerah lebih banyak memberitakan tentang potensi ekonomi di daerahnya masing-masing tapi belum bisa sepenuhnya sampai sekarang, misalnya mereka seharusnya memperhatikan terus menerus tentang komoditas sawit, karet, kopi, investasi, industri dan proyek infrastruktur nasional di sini, seperti Kualanamu, Trans Sumatera dan lainnya (Wawancara Paul Kusuma, 22 Oktober 2014).

Para wartawan MedanBisnis dari daerah-daerah di Sumatera Utara danAceh saat diskusi dalam Rapat Kerja Redaksi pada 9-10 September 2012 mengungkapkan ada 8 (delapan) permasalahan dalam meliput isu ekonomi dan bisnis yang mereka hadapi di daerah masingmasing. Delapan permasalahan itu sebagai berikut:

Narasumber dari kalangan pengusaha dan pengambil kebijakan di pemerintahan daerah kurang memahami permasalahan ekonomi dan bisnis secara komprehensif.Kalaupun narasumber dari kalangan pengusaha dan pengambil kebijakan menguasai permasalahan biasanya cenderung tertutup, akibatnya mereka kerap kali tak berkomentar atau "no comment" kepada wartawan yang meminta wawancara atau konfirmasi mengenai isu ekonomi dan bisnis tertentu. Birokrasi informasi panjang, terutama di perusahaan atau instansi yang berkantor pusat di ibukota provinsi seperti Medan atau ibukota negara di Jakarta. Akibatnya para narasumber di daerah tidak berani menyampaikan informasi yang berkaitan dengan isu ekonomi dan bisnis yang dianggap sensitif sebelum berkordinasi terlebih dulu dengan atasannya di kantor pusat, baik di Kota Medan atau Kota Jakarta. Kegiatan ekonomi dan bisnis masih terbatas karena investasi belum maksimal di 
daerah.Mayoritas wartawan di daerah cenderung meliput isu umum sehingga memengaruhi agenda liputan wartawan yang ingin mengejar isu ekonomi dan bisnis. Peliputan ke kawasan industri tertentu, seperti perkebunan dan pertanian seringkali sulit dilakukan karena berada di pelosok dengan kondisi infrastruktur jalan yang buruk.Pemahaman wartawan terhadap permasalahan ekonomi dan bisnis masih sangat terbatas sehingga lemah untuk mengembangkan isu liputan bidang ini.Kordinasi dan bekal dari redaksi untuk meliput permasalahan ekonomi dan bisnis di daerah dianggap masih belum memadai, jadi perlu diperkuat secara terus menerus.

Kordinator Daerah Mulyadi Hutahaean menambahkan permasalahan utama para wartawan meliput perekonomian dan bisnis berada pada kemampuan dan kemauan mereka.Soal kemampuan dan kemauan wartawan meliput berita ekonomi dan bisnis di daerah merupakan masalah utama, tetapi kita terus mengarahkan mereka untuk menggarap berita ekonomi misalnya tentang potensi daerah dan komoditas unggulan pertanian, perkebunan, perikanan dan peternakan, dan ada beberapa wartawan yang mulai konsisten tiap hari menuliskannya (Wawancara Mulyadi Hutahaean, 4 Desember 2014).

Namun di tengah permasalahan tersebut pengelola redaksi sebenarnya sudah memahami orientasi atau arah pemberitaan Harian MedanBisnis sebagai suratkabar ekonomi lokal, sebagaimana diungkapkan oleh Kordinator Liputan Iwan Guntara.MedanBisnis memperhatikan peristiwa ekonomi yang menyangkut nasib orang banyak atau yang sedang menjadi perhatian publik. Namun berita berskala mikro dan lokal lebih diprioritaskan, ketimbang berskala makro dan nasional. Kecuali, berita makro dan nasional itu menyangkut nasib atau terkait dengan masyarakat Sumatera Utara. (Wawancara Iwan Guntara, 10 November 2014)

Pemimpin Redaksi Bersihar Lubis mengakui berita ekonomi makro dan nasional juga menjadi perhatian MedanBisnis jika berdampak kepada masyarakat lokal, demikian pula terhadap berita ekonomi internasional.Kebijakan ekonomi nasional yang penting tentu saja tetap kita ambil, apalagi kalau kebijakan itu berdampak kepada daerah. Begitu pula berita ekonomi internasional yang berdampak bagi daerah, misalnya tindakan kampanye hitam terhadap sawit di Eropa karena Sumut penghasil sawit, memang agak jarang tapi pernah terjadi hal seperti itu, demikian pula soal MEA (Masyarakat Ekonomi Asean) yang juga pasti berdampak ke Sumatera Utara. Pokoknya faktor proximity sangat menentukan dalam pemberitaan ekonomi dan bisnis di koran ini, apalagi MedanBisnis adalah suratkabar lokal, jadi harus mempertimbangkan isu-isu lokal atau isu-isu nasional dan internasional yang berdampak kepada masyarakat di sini. (Wawancara Bersihar Lubis, 26 Oktober 2014)

Suratkabar sebagai media massa memang harus memerhatikan faktor proximity atau kedekatan peristiwa, baik secara geografis maupun psikologis, dalam pemberitaan untuk publik yang menjadi segmentasi pembacanya. McQuail mengatakan unsur proximity geografis dan proximity psikografis merupakan ukuran untuk menentukan relevansi (relevance) pemberitaan media, disamping unsur news value lainnya yaitu timeliness, significance, prominence, dan magnitude (Yusuf, 2011: 307).

\section{Faktor "Hierarki Pengaruh" dalam Kebijakan Editorial}

Adolph Ochs, pemilik New York Times, mengatakan suratkabar seharusnya memberikan berita yang tak berpihak, tanpa ketakutan atau miring sebelah, tanpa memandang partai, sekte, atau kepentingan lain yang terlibat (Kovach dan Rosentiel, 2001: 60).

Pernyataan Ochs itu menunjukkan suratkabar seharusnya menerapkan jurnalisme yang independen dalam menunaikan tugas pemberitaan. Kovach dan Rosentiel (2001: 4) mengemukakan informasi yang independen, dapat diandalkan, akurat dan komprehensif dibutuhkan anggota masyarakat untuk hidup merdeka. 
Vol 1 No. 1, 2018, 15-48

DOI: https://doi.org/10.30596/persepsi.v1i1.2504

American Society of Newspaper Editors menuliskan independensi itu sebagai satu poin penting dalam kode etik organisasi ini, yang berbunyi: "Indepedensi: bebas dari semua kewajiban, kecuali kesetiaan terhadap kepentingan publik adalah vital" (Kovach \& Rosentiel, 2001: 61-62).

Dewan Pers di Indonesia juga menunjukkan pentingnya independensi itu bagi wartawan dalam menjalankan profesinya dengan memasukkannya dalam Kode Etik Jurnalistik (KEJ). Pasal 1 KEJ itu berbunyi: "Wartawan Indonesia bersikap independen, menghasilkan berita yang akurat, berimbang, dan tidak beritikad buruk."

Independen dalam hal ini ditafsirkan dengan arti memberitakan peristiwa atau fakta sesuai dengan suara hati nurani tanpa campur tangan, paksaan, dan intervensi dari pihak lain, termasuk pemilik perusahaan pers (Penafsiran Pasal 1 Ayat (a) KEJ).

Perkembangan industri membuat pers sebagai media jurnalisme juga diakui sebagai lembaga ekonomi. Pasal 3 Ayat 2 Undang-Undang No 40 Tahun 1999 tentang Pers menyebutkan "Pers nasional dapat berfingsi sebagai lembaga ekonomi. Adapun penjelasan pasal ini disebutkan bahwa "Perusahaan pers dikelola sesuai dengan prinsip ekonomi, agar kualitas pers dan kesejahteraan para wartawan dan karyawannya semakin meningkat dengan tidak meninggalkan kewajiban sosialnya" (Penjelasan UU No 40 Tahun 1999 tentang Pers).

Sukardi (2009: 26-27) mengatakan dalam konteks perekonomian, pelaksanaan kemerdekaan pers yang berkualitas ditentukan oleh beberapa faktor, diantaranya struktur kepemilikan pers, struktur industri pers, perundangan-undangan yang berlaku, dan kebijakan perekonomian. Sukardi (2009: 10-26) menegskan fungsi sebagai lembaga perekonomian, membuat pers menjadi industri yang memiliki keterkaitan dengan banyak sektor lain sehingga mampu menampung banyak tenaga kerja dengan perputaran dana melimpah, tetapi struktur kepemilikan pers juga memberikan hak kontrol kepada pemilik atas berita.

Pendapat itu menunjukkan selain segmentasi pembaca dan arah pemberitaan suratkabar, Severin-Tankard (2005: 277-278) mengutip Shoemaker dan Reese menyebut ada lima level lain sebagai faktor yang ikut memengaruhi pemberitaan media, yaitu level individual, rutinitas media, organisasi media, level ekstramedia, dan level ideologi. Faktor ini disebut sebagai "hierarki pengaruh" dimana level ideologi menempati puncak hierarki memengaruhi kebijakan editorial media massa, termasuk suratkabar.

\section{Level Individual}

Pemaparan terdahulu yang berdasarkan teori dalam penelitian ini menunjukkan proses pembuatan berita juga tergantung kemampuan atau kapasitas wartawan sebagai individu. Shoemaker dan Reese (Severin-Tankard, 2005: 277) mengemukakan ada pengaruh dari pekerja media secara individu, diantara pengaruh-pengaruh ini adalah karakteristik pekerja komunikasi, latarbelakang professional dan kepribadian, sikap pribadi dan peran-peran professional.

Kondisi itu juga berlaku di Harian MedanBisnis. Pencapaian yang diperoleh suratkabar ini tidak terlepas dari pengaruh individu setiap wartawan dengan kemampuan dan keahlian profesional masing-masing. Wakil Pemimpin Umum Paul Kusuma mengakui kapasitas wartawan dan redaktur di suratkabar ini cukup beragam. ...yang saya lihat sehari-hari ada beberapa wartawan di Medan yang bagus, mereka bekerja lebih rapi. Tapi ini kan yang saya perhatikan, bukan berarti yang lain jelek semua. Redaktur juga masih bolehlah, lumayan, meski yang tidak bagus ada juga. Tapi saya rasa Pak Bersihar lebih tahu tentang kapasitas para redaktur, karena saya kurang tahu bagaimana tulisan mereka, bagaimana mereka kalau ketemu orang dan lainnya, tapi paling tidak mereka (para redaktur MedanBisnis) ya lumayanlah...(Wawancara Paul Kusuma, 26 Oktober 2014)

Pengakuan Paul Kusuma itu dipertegas oleh Pemimpin Redaksi Bersihar Lubis dengan memberi penjelasan sebagai berikut: Teman-teman memang mempunyai kemampuan, baik pengalaman maupun keahlian di bidang jurnalistik, tapi memang pemahaman mereka secara khusus terhadap berita ekonomi dan bisnis masih belum ideal, tetapi mereka sudah mencoba belajar meskipun bertahap, terlihat dalam rapat budget setiap sore sering terjadi perdebatan tentang isu ekonomi dan bisnis yang akan kita garap, masing-masing memberi masukan dari sudut pandangnya, saya kira ini proses belajar untuk memahami arah pemberitaan MedanBisnis sebagai suratkabar ekonomi dan bisnis. (Wawancara Bersihar Lubis, 26 Oktober 2014). 
Vol 1 No. 1, 2018, 15-48

DOI: https://doi.org/10.30596/persepsi.v1i1.2504

Paul Kusuma (dalam wawancara 22 Oktober 2014) dan Bersihar Lubis (dalam 26 Oktober 2014) mengakui keadaan tersebut tak terlepas dari latarbelakang pengalaman profesional para wartawan Harian MedanBisnis yang kebanyakan berasal dari suratkabar umum. Latarbelakang masing-masing individu awak redaksi itulah yang masih mewarnai pemberitaan suratkabar ini selama ini.

\section{Level Rutinitas Media}

Rutinitas media ikut memengaruhi pemberitaan karena para wartawan terikat pola kerja yang permanen. Mereka terpengaruh pola kerja yang rutin itu dalam menunaikan tugas pemberitaan setiap hari. Shoemaker dan Reese (Severin-Tankard, 2005: 277-278) mengemukakan pemberitaan media massa dipengaruhi oleh praktik-praktik komunikasi sehari-hari communicator/orang penghubung, termasuk deadline/batas waktu dan kendala waktu lainnya, kebutuhan ruang dalam penerbitan, struktur piramida terbalik untuk menulis berita, nilai berita, standar objektivitas, dan kepercayaan reporter pada sumber-sumber berita.

Pemimpin Redaksi MedanBisnis Bersihar Lubis (dalam wawancara, 26 Oktober 2014) mengatakan alokasi ruang untuk berita ekonomi dan bisnis serta deadline yang cukup ketat memengaruhi pemberitaan suratkabar ini. Kondisi ini menjadi rutinitas yang mengikat para wartawan dan awak redaksi dalam menunaikan tugas pemberitaan setiap hari.Iya, MedanBisnis memang mempunyai enam belas halaman untuk berita ekonomi dan bisnis, inilah yang harus diisi setiap hari dengan deadline cukup ketat setiap malam supaya suratkabar ini dapat terbit lebih cepat sehingga bisa segera tiba di tangan pembaca lebih pagi. Soalnya, para pebisnis adalah orang yang selalu terburu-buru, jadi kami harus bisa mengimbangi mereka dengan terbit lebih cepat untuk memberikan informasi dan berita yang mungkin mereka perlukan sebagai referensi. Dengan keadaan ini kadangkala ada berita yang agak terasa kurang "asam dan garamnya" tapi kami tetap berusaha memberitakan dengan maksimal, dalam arti objektif, berimbang dan sebagainya. Keadaan ini, harus kami akui, juga membuat berita lebih banyak ditulis dalam bentuk straight news dengan struktur piramida terbalik, tetapi untuk pristiwa human interest seperti suka duka petani karet di tengah kemerosotan harga, perjuangan ibu-ibu yang berdagang cabai atau bawang untuk membiayai sekolah anak-anaknya biasanya ditulis dalam bentuk feature yang lebih menyentuh dan enak dibaca. Penulisan berita feature ini menuntut keahlian wartawan yang menulisnya, demikian pula redaktur sewaktu mengeditnya, jadi biasanya butuh proses lebih lama menyiapkan dan menyajikannya di suratkabar. (Wawancara Bersihar Lubis, 26 Oktober 2014)

Kordinator Liputan Iwan Guntara mengakui rutinitas itu memengaruhi produktivitas para wartawan. Dia mengemukakan sebagai berikut:Memang masih banyak wartawan di Kota Medan masih menulis beritastraight news, itu karena lebih cepat dan mudah, apalagi mereka dituntut menyetor sedikitnya tiga berita dengan deadline yang sudah ditentukan setiap hari. Begitupun, sesekali kalau ada proyeksi untuk menulis feature tetap harus dilakukan, karena biasanya kalau sudah diproyeksikan berarti sudah dialokasikan untuk dimuat di halaman mana, biasanya di halaman satu ekonomi atau halaman lain. (Wawancara Iwan Guntara, 10 November 2014).

Persoalan senada juga dikemukakan oleh Kordinator Daerah Mulyadi Huatahaean. Wartawan di daerah kebanyakan menulis berita dalam bentuk straight news karena lebih mudah dan cukup membantu untuk menulis dengan cepat, selain mereka juga jarang yang menguasai feature. Persoalan deadline pengiriman berita juga membuat mereka lebih memilih menulis berita dengan straight news . (Wawancara Mulyadi Hutahaean,4 Desember 2014)

Dari uraian di atas dapat disimpulkan bahwa keterbatasan halaman, deadline, perhatian terhadap kepentingan pebisnis sebagai pelanggan atau pembaca, kemampuan atau skill wartawan, ketentuan wajib menyetor minimal tiga berita, dan struktur piramida terbalik menjadi rutinitas yang mengikat dalam proses kerja para wartawan dan awak redaksi Harian MedanBisnis. Rutinitas ini memengaruhi pemberitaan suratkabar ini yang cenderung menyajikan berita dalam bentuk straight news.

\section{Level Organisasi Media}

Brooks dkk. (1988: 31-35) menyebutkan ada tiga tipe organisasi suratkabar, yaitu kecil (small), menengah (medium-sized), dan besar (metropolitan). Suratkabar dengan struktur 
organisasi yang besar tentu mempekerjakan lebih banyak awak redaksi untuk mengoperasikan redaksional daripada suratkabar menengah dan suratkabar kecil yang mempekerjakan lebih sedikit staf redaksi.

Struktur organisasi itu membentuk sistem dan hubungan kerja di antara para awak redaksi di masing-masing suratkabar, yang kemudian memengaruhi pemberitaan sesuai tujuan perusahaan suratkabar tersebut. Shoemaker dan Reese (Severin-Tankard, 2005: 278) mengatakan organisasi media memiliki beberapa tujuan dan menghasilkan uang sebagai salah satu yang paling umum digunakan. Tujuan-tujuan organisasi media ini bisa berdampak pada pemberitaan melalui berbagai cara.

Pemimpin Redaksi Harian MedanBisnis Bersihar Lubis mengakui struktur organisasi suratkabar cukup menentukan untuk mendukung tugas pemberitaan guna mencapai tujuan perusahaan, apalagi jika para awak redaksi mau bekerja keras melakukan inisiatif dan inovasi dalam menunaikan pekerjaan masing-masing....organisasi redaksi kita sebenarnya cukup memadai, kita mempunyai Kordinator Liputan (Kota) dan Kordinator Liputan Daerah, yang banyak suratkabar lain di Medan tidak mempunyainya karena hanya menugaskan redaktur pengelola halamannya mengordinasikan tugas-tugas peliputan ke reporter dan koresponden sehingga mereka seringkali tidak fokus. Kita juga punya redaktur-redaktur bidang ekonomi sesuai rubrikasi masingmasing, seperti Industri, Perdagangan, UKM, Infrastruktur, Agribisnis, Tapanuli Bisnis, Aceh Bisnis, dan lainnya. Masalahnya mungkin teman-teman redaktur masih kurang inisiatif, inovasi dan kerja keras untuk menjalankan tugas masing-masing, kalau tidak mungkin koran ini bisa lebih menonjol lagi. (Wawancara Bersihar Lubis, 26 Oktober 2014).

Kordinator Liputan Iwan Guntara sepakat struktur organisasi MedanBisnis sudah cukup memadai, meski masih menyarankan perbaikan. ...struktur organisasi (MedanBisnis) sudah memadai tapi akan lebih baik jika disempurnakan lagi. Misalnya, Wapemred dan Redpel tidak lagi terlibat sebagai redaktur. Tapi lebih fokus kepada upaya-upaya pengembangan keredaksian. (Wawancara Iwan Guntara, 10 November 2014)

Pendapat kritis juga disampaikan oleh Kordinator Daerah Mulyadi Hutahaean. Dia mengemukakan sebagai berikut....kalau di redaksi struktur organisasinyanya sudah cukup memadai, hanya saja belum menjalankan tugasnya secara serius dan maksimal sesuai dengan tugas dan fungsinya masing-masing. (Wawancara Mulyadi Hutahaean, 4 Desember 2014)

Wakil Pemimpin Umum Harian MedanBisnis Paul Kusuma juga mengakui pengaruh organisasi terhadap pemberitaan, karena itu berencana mengembangkannya untuk mencapai tujuan suratkabar ini.... saya sendiri tentu mau koran ini terus berkembang, semua wartawan bisa membuat berita sendiri dengan baik, tidak sama atau diambil dari Yahoo atau KapanLagi maupun Tempo meski pembaca tidak mengetahuinya, tapi orang media pasti tahu kan, makanya dalam pikiran saya kalau semua sudah lebih terorganisir pasti kita bisa lebih baik...(Wawancara Paul Kusuma, 22 Oktober 2014).

Keinginan Paul Kusuma mendapatkan berita yang tidak sama dari media lain merupakan upaya memberikan berita eksklusif untuk menarik perhatian masyarakat terhadap MedanBisnis sehingga bisa membuat suratkabar ini menjadi lebih dikenal dan berkembang maju. Rapat Kerja Rapat Kerja Redaksi Harian MedanBisnis pada 21-22 Januari 2011 juga merumuskan nilai berita khusus untuk membuat suratkabar ini berbeda, yaitu unik, eksklusif, dan inspiratif. Kalau harapan ini tercapai tentu akan memudahkan MedanBisnis mencapai berbagai tujuannya, yang muaranya adalah menjadi suratkabar ekonomi lokal yang besar dan mapan.

\section{Level Ekstramedia}

Berbagai pihak di luar organisasi media seringkali ikut memengaruhi pemberitaan media. Shoemaker dan Reese (Severin-Tankard, 2005: 278) mengatakan pengaruh-pengaruh ini datang dari kelompok-kelompok kepentingan yang melobi untuk mendapatkan persetujuan (atau menentang) jenis-jenis isi tertentu, orang-orang yang menciptakan pseudoevent untuk mendapatkan liputan media, dan pemerintah yang mengatur isi secara langsung dengan undang-undang pencemaran nama baik dan ketidaksopanan. Yusuf (2011: 311) menambahkan pengaruh juga 
datang dari sumber penghasilan media, berupa pemasang iklan, penanam modal, dan pihak eksternal seperti pemerintah dan lingkungan bisnis.

Pihak media sulit menolak pengaruh-pengaruh eksternal itu bahkan harus berkompromi supaya bisa survive, mengingat mereka juga merupakan sumber daya yang menghidupinya. Peneliti juga menemukan pengaruh level ekstramedia itu dalam pemberitaan Harian MedanBisnis, sebagaimana pengakuan Paul Kusuma sebagai Wakil Pemimpin Umum suratkabar ini. Dia menyebutkan adanya pengaruh politik dalam masa pemilihan presiden 2014 yang menampilkan dua calon presiden, yaitu Joko Widodo dari Partai Demokrasi Indonesia Perjuangan (PDIP) dan Prabowo Subianto dari Gerindra, terhadap pemberitaan MedanBisnis. ...banyak orang PDIP (yang mengusung Jokowi) dekat dengan Pak Supandi (orangtua Paul Kusuma, pemilik Harian Analisa dan MedanBisnis) seperti Darsen, Brilian Mokhtar, Hasyim, Sofyan Tan, mereka yang sering bicara dengan Bapak (Supandi), tapi kan ada juga orang dari Gerindra (Parpol yang dipimpin Prabowo) seperti Gus Irawan juga dekat dengan Pak Supandi, makanya kita tak boleh terlalu menyolok memberitakan Jokowi, harus ada juga Prabowo, tapi jangan pula seperti koran lain yang tetap membesar-besarkan Prabowo dengan memberitakan dia menang di daerah-daerah tertentu meski sudah kalah secara nasional, kita tak boleh begitu... (Wawancara Paul Kusuma, 22 Oktober 2014)

Pengaruh pihak pemerintah dan relasi iklan diakui oleh Paul Kusuma ikut menjadi pertimbangan dalam pemberitaan Harian MedanBisnis, seperti mengenai permainan harga dalam pasar murah yang digelar Pemerintah Kota (Pemko) Medan menjelang lebaran Idul Fitri pada Juli 2014 lalu. Suratkabar ini dalam beberapa pemberitaannya mengungkapkan anggaran subsidi untuk harga bahan pokok tak perlu disediakan oleh Pemko Medan, karena pihak Dinas Perindustrian dan Perdagangan (Desperindag) sudah mendapat diskon harga dari produsen maupun distributor bahan pokok sehingga bisa menjual dengan murah. Para produsen dan distributor itu mendukung program pasar murah dengan memberi diskon karena membantu pamasaran produk mereka, makanya bersama pihak Pemko Medan ikut 'mendekati' pihak MedanBisnis yang mengungkapkan 'permainan' dalam program tersebut untuk menghentikan pemberitaannya. Pertimbangan menghentikan berita itu datang dari permintaan relasi distributor bahan pokok yang menjadi pemasang iklan . Mereka minta tolong untuk tak meneruskan pemberitaan tersebut. (Wawancara Paul Kusuma, 22 Oktober 2014)

Paul Kusuma menambahkan pengaruh relasi iklan tidak terlalu besar dalam pemberitaan Harian MedanBisnis. Kalau pun ada yang meminta 'perhatian' dalam pemberitaannya sebagian datang dari pemasang iklan Harian Analisa yang menjadi induk Harian MedanBisnis. Ya (pengaruh relasi iklan) memang ada, tapi tidak terlalu berpengaruh, karena pemasang iklan kita belum terlalu banyak, apalagi tidak semua pemasang iklan ada kasus. Lagi pula kalaupun semua ada kasus, lalu mereka tutup dengan iklan, kita tak boleh beritakan, lama-lama koran ini tidak bisa terbit lagi nanti...tapi selama ini iklan tak terlalu berpengaruh terhadap pemberitaan kita. (Wawancara Paul Kusuma, 22 Oktober 2014).

Pemimpin redaksi Bersihar Lubis mengakui ada pengaruh relasi iklan dalam pemberitaan Harian Medanbisnis, disamping pengaruh dari pihak pemerintah dan kelompok kepentingan tertentu. Tetapi pengaruh itu tidak boleh melampaui kepentingan publik untuk menjalankan fungsi sejati media, meski untuk kasus-kasus tertentu yang berhubungan dengan kepentingan owner atau pemilik tetap harus ditanyakan pemuatan beritanya. Ini grey area, area abu-abu, dibilang tak ada (pengaruh tersebut) ya pasti ada, namun kepentingan publik tetap prioritas...Memang berita-berita tertentu yang menjadi perhatian owner dan berkaitan dengan keterlibatan kepentingan mereka perlu ditanyakan pemuatannya, tapi saya kira redaksi masih cukup independen sampai sekarang. (Wawancara Bersihar Lubis, 26 Oktober 2014)

Kordinator Liputan Iwan Guntara juga mengemukakan MedanBisnis selalu mempertimbangkan pengaruh yang datang dari pemasang iklan, relasi dengan penguasa, tekanan kelompok kepentingan tertentu.Permintaan pemasang iklan, relasi dengan penguasa, tekanan 
kelompok kepentingan tertentu terkait penerbitan berita selalu dilayani meski masih 50:50 dengan kepentingan publik. (Wawancara Iwan Guntara, 10 November 2014)

Koordinator Daerah Mulyadi Hutahaean memberikan pengakuan senada mengenai pengaruh dari pemasang iklan, relasi dengan penguasa, tekanan kelompok kepentingan tertentu dalam pemberitaan Harian MedanBisnis. Ada berita tertentu tidak bisa disiarkan atau harus disiarkan karena terkait relasi perusahaan atau pengiklan karena saat ini media sudah menjadi industri...Sampai sekarang (MedanBisnis) masih lebih mengutamakan kepentingan pemasang iklan, relasi dan kepentingan owner. (Wawancara Mulyadi Hatahaean, 4 Desember 2014).

Pemaparan para informan menunjukkan bahwa Harian Medanbisnis tak terlepas dari kondisi ekonomi politik media di Indonesia, termasuk di Medan, Sumatera Utara. Tim LSPP (2005: 6-7) mengemukakan kondisi ekonomi politik media di Indonesia memperlihatkan bahwa dalam beberapa hal media tak bisa menghindar dari tarikan juga intervensi bisnis dari para konglomerat media atau elite lokal yang berafiliasi dengan partai politik tertentu yang menanamkam modalnya dalam bisnis media.

Pertimbangan bisnis dan berbagai kepentingan pemilik media yang berkaitan dengan relasinya selalu memengaruhi pemberitaan media. Bahkan, menurut Tim LSPP (2005-7), pemberitaan media tersebut terkesan berpihak pada arus pasar dan arus kepentingan.

\section{Level Ideologi}

Ideologi merupakan pikiran dasar dan orientasi pokok yang menjadi pegangan hidup masyarakat di satu negara. Karena itu, Yusuf (2011: 311) mengatakan, level ideologi diartikan sebagai kerangka berpikir atau kerangka referensi individu dalam menafsirkan realitas dan bagaimana mereka menghadapinya. Parapat (1985: 10) menambahkan sebuah berita dimuat tidak terlepas dari keadaan masyarakat, latarbelakang pemiliknya, dan visi-misi yang diemban media.

Harian MedanBisnis mempunyai visi ingin menjadi suratkabar terkemuka di Sumatera dalam menyajikan berita ekonomi dan bisnis, sedangkan misinya adalah memberikan masyarakat berita ekonomi dan bisnis dari hasil kerja jurnalistik yang berkualitas. Visi-misi itu membuat suratkabar ini menggunakan motto "Membangun Indonesia yang Lebih Baik" untuk menunjukkan tujuan kehadirannya.

Dalam pemberitaan Harian MedanBisnis, faktor ideologi tersebut menjadi pertimbangan dalam menentukan kebijakan editorial, sebagaimana dikemukakan oleh Wakil Pemimpin Umum Paul Kusuma yang mengutip pesan orangtuanya Supandi Kusuma selaku owner suratkabar ini.

...sebagai koran bisnis supaya kita tidak mempersulit pebisnis dengan mencari-cari kasusnya, kecuali kasusnya sudah sampai ke penegak hukum seperti kepolisian, misalnya pengusaha ditangkap polisi tetap kita beritakan.(Wawancara Paul Kusuma, 22 Oktober 2014)

Kebijakan yang menjadi koridor dalam pemberitaan Harian MedanBisnis itu dipertegas oleh Pemimpin Redaksi Bersihar Lubis. Dia mengatakan sebagai berikut: Saya concern kepada dua faktor utama dalam menentukan penyiaran berita, yaitu pertama keberimbangan berita, artinya setiap berita sesuai prinsip jurnalistik harus berimbang, apalagi kalau menyangkut kasus ekonomi dan bisnis yang menjadi fokus pemberitaan kita, tidak boleh sebelah pihak, harus dua belah pihak, bahkan banyak pihak kalau memang banyak pihak terlibat dalam kasus itu, karena kita ingin menjadi koran yang pemberitaannya berimbang supaya masyarakat pembaca mendapat informasi yang utuh, tidak sepotong-sepotong. Faktor kedua, perusahaan yang memberi perhatian terhadap pemberdayaan ekonomi masyarakat dan berkontribusi bagi pertumbuhan ekonomi daerah perlu mendapat perhatian MedanBisnis juga, tetapi bukan berarti perusahaan seperti ini tidak boleh diberitakan dengan kritis kalau dia salah, tetap kita beritakan dengan menjaga keseimbangan pemberitaannya, jadi pemberitaannya tidak sebelah pihak atau berdasarkan sentimen emosional sehingga terjebak dalam "jurnalisme marah", tujuan pemberitaan kritis tapi seimbang itu ya supaya perusahaan ini menjadi lebih baik lagi. MedanBinis menurunkan beritanya untuk memenuhi kebutuhan publik terhadap informasi, karena perusahaan yang memerhatikan kepentingan publik, seperti mempunyai program pembinaan lingkungan, mengembangkan ekonomi masyarakat dan pembangunan sosial, baik melalui program CSR dan lainnya, berarti mempunyai misi serupa 
Vol 1 No. 1, 2018, 15-48

DOI: https://doi.org/10.30596/persepsi.v1i1.2504

dengan koran ini. Perusahaan itu patut menjadi mitra MedanBisnis untuk menjaga dan membela kepentingan masyarakat. (Wawancara Bersihar Lubis, 26 Oktober 2014).

Kordinator Liputan Iwan Guntara mengakui kebijakan tersebut menjadi panduan bagi awak redaksi, termasuk reporter, dalam pemberitaan Harian MedanBisnis.Visi dan misi Medanbisnis sebagai koran ekonomi yang tercermin dalam kebijakan redaksi selalu menjadi panduan dalam setiap peliputan maupun pemberitaan. Meski pun hal tersebut belum terealisasi 100\%. (Wawancara Iwan Guntara, 10 November 2014).

Pengakuan serupa juga dikemukakan oleh Kordinator Daerah Mulyadi Hutahaean meski dalam pelaksanaannya masih terhambat produktivitas wartawan dalam menghasilkan berita ekonomi dan bisnis, khususnya dari daerah.Kebjakan pemberitaan yang merupakan cerminan visi misi Harian MedanBisnis memang menjadi panduan dalam pemberitaan tetapi masih belum berjalan sesuai dengan harapan dan itu dibuktikan dengan masih terbatasnya berita ekonomi dan bisnis yang ditulis oleh wartawan dari daerah. (Wawancara Mulyadi Hutahaean, 4 Desember 2014)

Pemberitaan pers, termasuk suratkabar, memang selalu dipengaruhi oleh ideologi masyarakat di suatu negara, dimana para pemilik dan pengelolanya juga merupakan bagian masyarakat tersebut. De Rooy (Oetama, 1987: 176) mengatakan pers di suatu negara akan selalu dipengaruhi oleh pikiran dasar dan orientasi pokok yang sedang berlaku dalam masyarakatnya.

Pemilik dan pengelola media massa, seperti suratkabar biasanya menunjukkan ideologi sebagai pikiran pokok atau orientasi dasar yang menjadi pegangan hidup tersebut dalam bentuk visi misi, kebijakan, dan operasional pemberitaan. Shoemaker dan Reese (Severin-Tankard, 2005: 278) menyebutkan ideologi memengaruhi isi media massa dengan banyak cara.

\section{Simpulan}

Pemimpin Redaksi Harian MedanBisnis mempunyai wewenang menentukan kebijakan editorial, dengan mempertimbangkan kepentingan pemilik (owner) suratkabar ini. Pemilik atau representasi pemilik yang dipegang oleh Wakil Pemimpin Umum selalu memberi perhatian kepada pemasang iklan, relasi dengan penguasa, dan kelompok kepentingan tertentu yang kerap ditumpangkan kepada redaksi dalam menentukan dan menjalankan kebijakan editorial. Dia memberi masukan menyangkut perhatian dan kepentingannya itu melalui dua cara, yaitu dalam rapat redaksi atau langsung kepada Pemimpin Redaksi dan awak redaksi di newsroom.

Rancangan kebijakan editorial yang telah ditentukan oleh Pemimpin Redaksi setelah mendengarkan 'masukan' dari pemilik akan dibawa ke rapat redaksi untuk dimatangkan sekaligus disosialisasikan kepada para redaktur. Para redaktur akan menggunakan kebijakan editorial itu sebagai panduan dalam menunaikan tugasnya menseleksi, menyunting, dan menyiarkan berita, terutama dalam pemberitaan ekonomi dan bisnis di suratkabar ini.

Ada lima level, disamping segmentasi pembaca dan arah pemberitaan, sebagai faktor yang ikut memengaruhi kebijakan editorial dalam pemberitaan Harian MedanBisnis. Faktor-faktor itu dalam teori "hierarki pengaruh" dikenal sebagai level individual, rutinitas media, organisasi media, level ekstramedia, dan level ideologi.

Level individual berhubungan dengan latarbelakang pengalaman profesional para wartawan Harian MedanBisnis yang mayoritas berasal dari suratkabar umum. Level rutinitas berhubungan dengan alokasi ruang untuk berita ekonomi dan bisnis, perhatian terhadap segmentasi pasar, kewajiban menyetor minimal tiga berita, struktur penulisan berita, serta deadline yang cukup ketat membuat berita cenderung disajikan dalam bentuk straight news, jarang sekali dalam bentuk feature yang lebih enak dibaca. Level organisasi media mencakup struktur organisasi suratkabar yang sudah cukup memadai dimiliki MedanBisnis meski dalam pelaksanaannya perlu perbaikan guna mencapai tujuan perusahaan. Level ekstramedia adalah berbagai pihak di luar organisasi media yang seringkali ikut memengaruhi pemberitaan media, seperti pemasang iklan, penanam modal, dan pihak eksternal seperti pemerintah dan lingkungan bisnis. Level ideologi berhubungan dengan pegangan hidup masyarakat di satu negara yang tampil dalam bentuk visi misi, kebijakan, dan operasional pemberitaan, dalam hal ini Harian MedanBisnis mempunyai komitmen mendukung kegiatan bisnis dengan pemberitaan seimbang apalagi jika perusahaan yang melakukan 
kegiatan bisnis itu memberi perhatian terhadap pemberdayaan ekonomi masyarakat serta berkontribusi bagi pertumbuhan ekonomi daerah.

\section{Referensi}

Abrar, Ana Nadhya. 1992. Pers Indonesia Berjuang Menghadapi Perkembangan Masa. Liberty, Yogyakarta.

Armada SA., Wina. 1989. Wajah Hukum Pidana Pers. Pustaka Kartini, Jakarta.

Arikunto, Suharmisi.1998.Prosedur Penelitian Suatu Pendekatan Praktek. Rineka Cipta, Jakarta.

Assegaf, Dja'far H. 1985. Jurnalistik Masa Kini: Pengantar Ke Praktek Kewartawanan. Ghalia Indonesia, Jakarta

Atmadi, T. 1975. Bunga Rampai Catatan Pertumbuhan Dan Perkembangan Pers Indonesia. Panca Simpati, Jakarta.

Bastian, Mayelus Dori. 2014. Manajemen Redaksional Dan Eksistensi Suratkabar Lokal [Studi Kasus tentang Manajemen Keredaksian Harian Umum Flores Pos Tahun 2013]. Program Pascasarjana Fakultas Ilmu Sosial Dan Politik Universitas Gajah Mada, Yogyakarta

Broder, David S. 1996. Berita Di Balik Berita. Pustaka Sinar Harapan, Jakarta

Brooks,Brian S., George Kennedy, Daryl R. Moen, Don Ranly. 1988. News Reporting And Writing. St. Martin's Press, New York.

Cangara, Hafied. 2004. Pengantar Ilmu Komunikasi. PT. RajaGrafindo Persada, Jakarta.

Chariri, Anis. 2009. Landasan Filsafat Dan Metode Penelitian Kualitatif. Universitas Diponegoro, Semarang

Curran, James \& Michael Gurevitch. 2000. Mass Media and Society. Arnold, London.

DeFleur, Melvin L., and Everette E. Dennis. 1985. Understanding Mass Communication. Houghton Mifflin, Boston.

Devito,Joseph.1997. Komunikasi Antar Manusia. Proffesional Books, Jakarta.

Djuroto,Totok. 2004. Manajemen Penerbitan Pers. PT Rosda Karya, Bandung.

Effendy, O.Uchyana. 1993. Dinamika Komunikasi. Remaja Rosdakarya,Bandung 2003. Ilmu, Teori, dan Filsafat Komunikasi. PT Citra Aditya, Bandung 2005. Ilmu Komunikasi Teori dan Praktek. PT.Rosdakarya, Bandung.

Eriyanto. 2007. Analisis Framing: Konstruksi, Ideologi, dan Politik Media. LKIS, Yogyakarta Feliza. 1982. Tanya Jawab Pers. Armico, Bandung.

Fink, Conrad. 1998. Strategic Newspaper Management. Random House, New York.

Fuller, Jack. 1996. News Values: Ideas for an Information Age. University of Chicago Press, Chicago.

Handoko, T. Hani.2003. Manajemen Edisi II.BPFE, Yogyakarta.

Haris, Sumadiria. 2006. Jurnalistik Indonesia: Menulis Berita dan Feature Panduan Praktis Jurnalis Profesional. Remaja Rosda Karya, Bandung. .2006. Metode Penelitian Kuantitatif, Kualitatif dan R \& D. Alfabeta, Bandung.

Hasanah, Erni Umi dan Danang Sunyoto. 2013.Pengantar Ilmu Ekonomi Makro. Caps, Jakarta.

Hemp, Paul. 1991. Business And Economic Reporting in Developing Countries. The Center for Foreign Journalist. VA.

Herman, E.S, \& Noam Chomsky. 1988. Manufacturing Consent: The Political Economy of The Mass Media. Pantheon, New York.

Iskandar, Maskun dan Atmakusumah. 2006. Panduan Jurnalistik Praktis: Mendalami Penulisan Berita dan Feature, Memahami Etika dan Hukum Pers. Lembaga Pers Dr. SoetomoFriedrich-Ebert-Stiftung, Jakarta.

Jahi, Amri. 1988. Komunikasi Massa Dan Pembangunan Pedesaan Di Negara-Negara Dunia Ketiga. Gramedia, Jakarta.

Jorgensen., Karin Wahl., and Thomas Hanitzsch. 2009. The Handbook of Journalism Studies. Routledge, New York.

Kamal, Nur Saipan. 2009. Manajemen Pemberitaan Di Suratkabar Harian Yogya. UIN Sunan Kalijaga, Yogya 
Kertapati, Ton. 1986. Dasar-Dasar Publisistik. Bina Aksara, Jakarta.

Kholil, Syukur (Ed). 2011. Teori Komunikasi Massa. Ciptapustaka Media Perintis, Bandung.

Kovach, Bill dan Tom Rosenstiel. 2001. Sembilan Elemen Jurnalisme. Yayasan Pantau, Institut Studi Arus Informasi, dan Kedubes AS, Jakarta

Kriyantono, Rachmat. 2006. Teknik Praktis Riset Komunikasi. Kencana Prenada, Jakarta

Kusumaningrat, Hikmat Purnama.2005. Jurnalistik Teori dan Praktek. PT. Remaja Rosda Karya, Bandung

McQuail, Dennis. 1987. Teori Komunikasi Massa. Penerbit Erlangga, Jakarta.

Meinanda, Teguh. 1981. Pengantar Ilmu Komunikasi dan Jurnalistik. Armico, Bandung

Mikhelsen, Brita. 1999. Metode Penelitian Parsipatoris dan Upaya-upaya Pemberdayaan. Yayasan Obor Indonesia, Jakarta.

Moleong, Lexi J. 2004. Metode Penelitian Kualitatif. PT Remaja Rosda Karya, Bandung

Mondry. 2008. Pemahaman Teori dan Praktik Jurnalistik. Ghalia Indonesia, Bogor

Morissan. 2013. Teori Komunikasi: Individu Hingga Massa. Kencana Prenada Media Group, Jakarta. Bandung

Mulyana, Deddy. 2007. Ilmu Komunikasi Suatu Pengantar. PT. Remaja Rosdakarya,

Mustoffa, Sumono. 1996. Menulis Berita Ekonomi dan Bisnis. KNI, Jakarta

Nugroho, Yanuar., dkk. 2012. Mapping Media Policy in Indonesia. CIPG dan Hivos, Jakarta.

Oetama, Jakoeb. 1987. Perspektif Pers Indonesia. LP3ES, Jakarta.

Parapat, S. Rochimah. 1985. Jurnalistik Pembangunan. Kelompok Studi Ilmu Publisitik/Komunikasi, Medan

Pareno, Sam Abede. 2003. Manajemen Berita Antara Idealisme dan Realita. Penerbit Papyrus, Surabaya.

Pusat Pembinaan Dan Pengembangan Bahasa. 2005. Kamus Besar Bahasa Indonesia. Departemen Pendidikan Nasional RI, Jakarta.

Rachmadi. 1988. Perbandingan Sistem Pers. Gramedia, Jakarta.

Rakhmat, Jalaluddin. 1992. Psikologi Komunikasi. Remaja Rosdakarya, Bandung. 2007. Metode Penelitian Komunikasi. PT. Gramedia Pustaka Utama, Jakarta.

Rivers, William L, Cs. 2003. Media Massa dan Masyarakat Modern. Prenada Media, Jakarta.

Ruslan, Rosady. 2003. Metode Penelitian Public Relation Dan Komunikasi. PT Raja Grafindo Persada, Jakarta.

Safrodin, Muhammad. 2010. Kebijakan Redaksional SKH Kedaulatan Rakyat Dalam Menentukan Berita Utama (Headline News). Universitas Islam Negeri Sunan Kalijaga, Yogyakarta Serrin, William. 2000. The Business of Journalism. The New Press, New York.

Severrin, Werner J dan James W. Tankard, Jr. 2005. Teori Komunikasi, Sejarah, Metode dan Terapan di Dalam Media Massa. Prenada Media, Jakarta.

Shoemaker, Pamela \& Stephen D. Reese. 1996. Mediating the Message. Longman, New York.

Siregar, Ashadi dan Rondang Pasaribu. 2000. Bagaimana Mengelola Media Korporasi-Organisasi.

Kanisius, Yogyakarta.

Sukardi, Wina Armada. 2009. Menakar Kesejahteraan Wartawan. Dewan Pers, Jakarta

Sukirno, Sadono. 2013. Mikroekonomi: Teori Pengantar. Rajagrafindo Persada. Depok.

Susanto, Astrid S. 1977. Komunikasi Dalam Teori Dan Praktek. Binacipta, Bandung. 1986. Filsafat Komunikasi. Binacipta, Bandung.

Suwardi,H.,1993. Peranan Pers dalam Politik di Indonesia. Pustaka Sinar

Harapan,Jakarta.

Tim LBH Pers. 2009. Penegak Hukum Melek Pers. LBH Pers, Jakarta

Tim LSPP. 2005. Media Sadar Publik: Media Lokal Mewartakan Korupsi dan Pelayanan Publik. LSPP, Jakarta

Vivian, John. 2008. Teori Komunikasi Massa. Kencana Prenada Media Group, Jakarta

Wursanto, Ig. 1984. Etika komunikasi Kantor. Kanisius, Yogyakarta. 
Vol 1 No. 1, 2018, 15-48

DOI: https://doi.org/10.30596/persepsi.v1i1.2504

Yusuf, Azwar.2011. Kebijakan Redaksi Liputan 6 SCTV Dalam Menentukan Berita Utama. Fisip Universitas Sultan Ageng Tirtayasa, Serang

Yusuf, Iwan Awaluddin. Media Lokal dalam Konstelasi Komunikasi Politik di Daerah dalam Jurnal Ilmu Sosial dan Politik, Volume 3, Maret 2011. 